WSRC-RP-98-4130, Rev. 1.1, Fina/

\title{
Interim Action Proposed Plan for the Chemicals, Metals, and Pesticides (CMP) Pits Operable Unit
}

by

J. Bradley

Westinghouse Savannah River Company

Savannah River Site

Aiken, South Carolina 29808

This paper was prepared in connection with work done under the above contract number with the U.S.

Department of Energy. By acceptance of this paper, the publisher and/or recipient acknowledges the U. S.

Government's right to retain a nonexclusive, royalty-free license in and to any copyright covering this paper, along with the right to reproduce and to authorize others to reproduce all or part of the copyrighted paper. 
This document was prepared in conjunction with work accomplished under Contract No. DE-AC09-96SR18500 with the U. S. Department of Energy.

\section{DISCLAIMER}

This report was prepared as an account of work sponsored by an agency of the United States Government. Neither the United States Government nor any agency thereof, nor any of their employees, makes any warranty, express or implied, or assumes any legal liability or responsibility for the accuracy, completeness, or usefulness of any information, apparatus, product or process disclosed, or represents that its use would not infringe privately owned rights. Reference herein to any specific commercial product, process or service by trade name, trademark, manufacturer, or otherwise does not necessarily constitute or imply its endorsement, recommendation, or favoring by the United States Government or any agency thereof. The views and opinions of authors expressed herein do not necessarily state or reflect those of the United States Government or any agency thereof.

This report has been reproduced directly from the best available copy.

Available for sale to the public, in paper, from: U.S. Department of Commerce, National Technical Information Service, 5285 Port Royal Road, Springfield, VA 22161, phone: (800) 553-6847, fax: (703) 605-6900

email: orders@ntis.fedworld.gov

online ordering: http://www.ntis.gov/help/index.asp

Available electronically at http://www.osti.gov/bridge

Available for a processing fee to U.S. Department of Energy and its contractors, in paper, from: U.S. Department of Energy, Office of Scientific and Technical Information, P.O. Box 62, Oak Ridge, TN 37831-0062,

phone: (865)576-8401,

fax: (865)576-5728

email: $\underline{\text { reports@ adonis.osti.gov }}$ 


\section{United States Department of Energy}

Savannah River Site

\section{Interim Action Proposed Plan for the Chemicals, Metals, and Pesticides (CMP) Pits Operable Unit (U)}

WSRC-RP-98-4130

\section{Rev. 1.1}

March 1999 


\author{
Chemicals, Metals, and Pesticides Pits \\ (080-17G, 080-17.1G, 080-18G, 080-18.1G, 080-18.2G, \\ $080-18.3 \mathrm{G}, 080-19 \mathrm{G})$
}

Interim Action Proposed Plan for the

Chemicals, Metals, and Pesticides (CMP) Pits Operable Unit (U)

WSRC-RP-98-4130

Rev. 1.1

March 1999

"I certify under the penalty of law that this document and all attachments were prepared under my direction or supervision in accordance with a system designed to assure that qualified personnel properly gather and evaluate the information submitted. Based on my inquiry of the person or persons who manage the system, the information submitted is, to the best of my knowledge and belief, true, accurate, and complete. I am aware that there are significant penalties for submitting false information, including the possibility of fines and imprisonment for knowing violations."

Date: $12 M A C 99$

Date:
Signature:

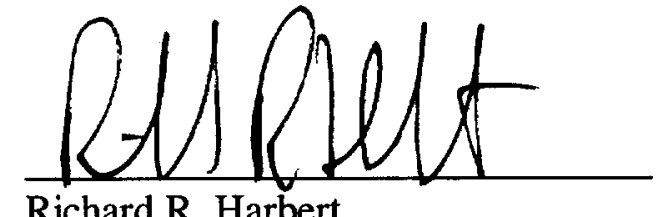

Vice President and General Manager

Environmental Restoration Division

Westinghouse Savannah River Company

Co-operator for the U.S. Department of Energy

Signature:
Cyptilia V. Anderson

Euvironmental Restoration Division

U.S. Department of Energy

Savannah River Operations Office

Owner and Co-operator 


\section{Disclaimer}

This report was prepared for the United States Department of Energy under Contract No. DE-AC09-96-SR18500 and is an account of work performed under that contract. Reference herein to any specific commercial product, process, or service by trademark, name, manufacturer or otherwise does not necessarily constitute or imply endorsement, recommendation, or favoring of same by Westinghouse Savannah River Company or by the United States Government or any agency thereof.

Printed in the United States of America

Prepared for the

U. S. Department of Energy

by

Westinghouse Savannah River Company

Aiken, South Carolina 


\section{EXECUTIVE SUMMARY}

This Interim Action Proposed Plan (IAPP) is issued by the United States Department of Energy (US DOE), which functions as the lead agency for SRS remedial activities, with concurrence by the United States Environmental Protection Agency (US EPA) and the South Carolina Department of Health and Environmental Control (SCDHEC). The purpose of this IAPP is to describe the preferred interim remedial action for addressing the Chemicals, Metals, and Pesticides (CMP) Pits Operable Unit and to provide an opportunity for public input into the remedial action selection process.

The CMP Pits Operable Unit consists of the pit area, ballast area, vadose zone, groundwater hot spot, and distal portion of the groundwater plume (distal plume). This interim remedial action applies to the (1) ballast area (including pit area perimeter surface soil), (2) vadose zone (pit area subsurface soil), and (3) groundwater hot spot. The groundwater hot spot includes the water table in and around the pit area within the $1000 \mu \mathrm{g} / \mathrm{l}$ volatile organic compound (VOC) isoconcentration contour. The distal plume is currently under investigation and will be addressed in a later remedial action.

The ballast area surface soil and the pit area perimeter surface soil near the ballast area were found to be contaminated with similar contaminants. Because of this circumstance, the pit area perimeter surface soil contamination is considered a single area of contamination primarily associated with the ballast area. The two areas will be collectively referred to as the "ballast area" throughout this document.

For the ballast area, this document represents the final decision for all response action to be taken. For the vadose zone and groundwater hot spot, this document is an interim action and does not represent a final decision.

\section{RFI/RI Results}

A Resource Conservation and Recovery Act (RCRA) Facility Investigation/Remedial Investigation (RFI/RI) was performed to determine the nature and * extent of contamination and the media of concern * (WSRC, 1997). The most significant findings from the characterization in support of this interim action are:
- The presence of high concentrations of organic solvents (i.e., tetrachloroethylene (PCE), trichloroethylene (TCE), and dichloromethane (DCM), etc.) in the vadose zone beneath the CMP Pits.

- The surface soil in the ballast area contains pesticides and polychlorinated biphenyls (PCBs); surface soils adjacent to the pit area contain several metals and a number of pesticides.

- The groundwater beneath the pit area contains PCE, TCE, and DCM above maximum $\therefore$ contaminant levels (MCLs).

\section{BRA Results}

The RCRA Facility Investigation/Remedial Investigation Report with Baseline Risk Assessment for the Chemicals, Metals, and Pesticides Pits (WSRC, 1997) indicates that:

- The ballast area poses a potential human health noncancer hazard and cancer risk associated with ingestion of produce and dermal contact with soil by a hypothetical future resident and future industrial worker from PCB (Aroclor1248 ) and pesticides (p,p'DDT).

- The ballast area surface soil poses a potential ecological hazard to terrestrial predators primarily due to bio-uptake of contamination in the food chain from pesticides.

- Concentrations of DCM, TCE, and PCE in groundwater exceed their respective MCLs.

- Concentrations of VOCs in the vadose zone are present at levels that indicate that these constituents may migrate to the groundwater.

Table 1 summarizes the constituents of concern (COCs) related to human health and ecological risks. 


\section{Remedial Goals}

The recommended RGs are protective of human health and the environment and are based upon the long-term strategy for the CMP Pits area. Although the CMP Pits area is located outside of the Industrial Use Zone (defined by Figure 3-3 of the FFA Implementation Plan), it is anticipated that the CMP Pits area will be a limited use area with restrictions similar to an industrial use zone. Unrestricted residential land use of the CMP Pits area would result in an unnecessary increase in human health risk due to excavation in the vadose zone and disturbance of the existing protective cap and drainage systems previously placed over the disposal pits. Restricting land use and institutional controls are necessary at this unit to provide continued protection to human health and the environment from exposure to contaminants and to prevent destruction of the previous remedial action.

Since the ballast area will be a final action, the recommended RGs are considered final RGs. The recommended $\mathrm{RG}$ for heptachlor is therefore based upon the industrial scenario and is protective of the industrial worker ( $1 \times 10^{-6}$ risk). The RG for Aroclor1248 is an action level based upon promulgated clean up standards (40CFR Part 761 Disposal of PCB; Final Rule) and which is also protective of the industrial worker. The RGs for dieldrin, endrin, $p, p^{\prime}$ DDD, p,p'-DDE, and p,p'-DDT are based upon ecological risks. Concentration based remediation goals are not specified for the vadose zone and the groundwater hot spot. Concentration based remediation goals will be developed during the final remedy selection. Effectiveness of the AS/SVE system on the vadose zone and groundwater hot spot contamination will be determined according to Section V, Performance Monitoring.

\section{Interim Remedial Action Objectives}

Final RAOs will be developed after the groundwater characterization in the vicinity of the CMP Pits is completed. Additional characterization efforts are ongoing to resolve the extent of groundwater plumes attributable to the CMP Pits. Understanding the extent of characterization is important to the selection of final remedial alternatives and appropriate RAOs. However, based on the existing data, interim remedial action objectives (IRAOs) for the ballast area, vadose zone and groundwater hot spot can be identified. The IRAOs are specific early action goals developed to reduce risk to human health and the environment. The IRAOs established for this IAPP are:

\section{Ballast Area}

- Prevent direct contact with PCB and pesticides contaminated surface soils, such that the contaminants of concern are not a continued significant risk to human health or the ecology.

\section{Vadose Zone}

- Treat the vadose zone soils beneath the pits where the combined PCE and TCE concentrations exceed $2,000 \mu \mathrm{g} / \mathrm{kg}$, with active treatment techniques as long as effective, with an overall objective to reduce the potential migration of solvents to the water table that result in contamination concentrations exceeding the MCL.

- Continue to provide infiltration control with a cover system in the vadose zone treatment area, to reduce the potential migration of solvents from the vadose zone to the water table.

\section{Groundwater Hot Spot}

- Treat the water table in the vicinity of the pits, within the $1,000 \mu \mathrm{g} / \mathrm{l}$ total VOC isoconcentration contour, with an objective to reduce concentrations and control migration of VOCs within the $1,000 \mu \mathrm{g} / \mathrm{l}$ contour.

This IAPP recommends the following interim remedial actions to meet the IRAOs:

\section{Ballast Area}

- Excavate the ballast area soils, dispose offsite, and backfill to grade.

Vadose Zone

- Conduct soil vapor extraction (SVE) in subsurface soils and install asphalt cover to provide infiltration control.

Groundwater Hot Spot

- Conduct air sparging (AS) in groundwater hot spot with SVE. 
Table 1. Summary of Interim Remedial Action Objectives and Remedial Goals for Soil and Groundwater

\begin{tabular}{|c|c|c|c|c|}
\hline $\begin{array}{l}\text { Areal } \\
\text { Media of } \\
\text { Concern }\end{array}$ & Interim Remedial Action Objective & $\begin{array}{l}\text { Potential } \\
\text { Exposure } \\
\text { Pathway }\end{array}$ & $\begin{array}{l}\text { Constituent } \\
\text { of Concern }\end{array}$ & $\begin{array}{c}\text { Concentration } \\
\text {-Based } \\
\text { Remediation } \\
\text { Goal } \\
\end{array}$ \\
\hline \multirow[t]{2}{*}{ Ballast Area } & \multirow[t]{2}{*}{$\begin{array}{l}\text { Prevent direct contact with PCB and pesticides } \\
\text { contaminated surface soils, such that the contaminants } \\
\text { of concern are not a continued significant risk to human } \\
\text { health or the ecology. }\end{array}$} & Direct contact & $\begin{array}{l}\text { Aroclor-1248 } \\
\text { heptachlor }\end{array}$ & $\begin{array}{l}<1000 \mu \mathrm{g} / \mathrm{kg}^{\mathrm{a}} \\
490 \mu \mathrm{g} / \mathrm{kg}^{\mathrm{a}}\end{array}$ \\
\hline & & $\begin{array}{l}\text { Ingestion of } \\
\text { prey }\end{array}$ & $\begin{array}{l}\text { dieldrin } \\
\text { endrin } \\
\text { DDD } \\
\text { DDE } \\
\text { DDT } \\
\end{array}$ & $\begin{array}{l}50 \mu \mathrm{g} / \mathrm{kg}^{\mathrm{b}} \\
60 \mu \mathrm{g} / \mathrm{kg}^{\mathrm{b}} \\
10 \mu \mathrm{g} / \mathrm{kg}^{\mathrm{b}} \\
20 \mu \mathrm{g} / \mathrm{kg}^{\mathrm{b}} \\
60 \mu \mathrm{g} / \mathrm{kg}^{\mathrm{b}} \\
\end{array}$ \\
\hline Vadose Zone & $\begin{array}{l}\text { Treat the vadose zone soils beneath the pits where the } \\
\text { combined PCE and TCE concentrations exceed } \\
2,000 \mu \mathrm{g} / \mathrm{kg} \text {, with active treatment techniques as long as } \\
\text { effective, with an overall objective to reduce the } \\
\text { potential migration of solvents to the water table that } \\
\text { result in contamination concentrations exceeding the } \\
\mathrm{MCL} \text {. } \\
\text { Continue to provide infiltration control with a cover } \\
\text { system in the vadose zone treatment area, to reduce the } \\
\text { potential migration of solvents from the vadose zone to } \\
\text { the water table. }\end{array}$ & $\begin{array}{l}\text { Infiltration to } \\
\text { groundwater }\end{array}$ & $\begin{array}{l}\text { DCM } \\
\text { PCE } \\
\text { TCE }\end{array}$ & $\begin{array}{l}\text { Not Applicable } \\
\text { Not Applicable } \\
\text { Not Applicable }\end{array}$ \\
\hline $\begin{array}{l}\text { Groundwater } \\
\text { Hot Spot }\end{array}$ & $\begin{array}{l}\text { Treat the water table in the vicinity of the pits, within } \\
\text { the } 1,000 \mu \mathrm{g} / 1 \text { total VOC isoconcentration contour, with } \\
\text { an objective to reduce concentrations and control } \\
\text { migration of VOCs within the } 1,000 \mu \mathrm{g} / \mathrm{l} \text { contour. }\end{array}$ & $\begin{array}{l}\text { Transport to } \\
\text { uncontaminated } \\
\text { portions of the } \\
\text { groundwater } \\
\text { aquifers }\end{array}$ & $\begin{array}{l}\text { DCM } \\
\text { PCE } \\
\text { TCE }\end{array}$ & $\begin{array}{l}\text { Not Applicable } \\
\text { Not Applicable } \\
\text { Not Applicable }\end{array}$ \\
\hline
\end{tabular}

Constituent RG units in $\mu \mathrm{g} / \mathrm{kg} .(1 \mu \mathrm{g} / \mathrm{kg}=1 \mathrm{ppb})$

\section{Footnotes:}

a Rationale for selection based on human health risk to protect future industrial worker.

b Rationale for selection based on target ecological risk quotient for birds of 1 .

Notes:

- Constituents are:

PCBs: Aroclor-1248

Pesticides: heptachlor, dieldrin, endrin, p,p'-DDD, p,p'-DDE, p,p'-DDT

VOCs: DCM, PCE, TCE

- The locations where acetone, 2-butanone (methyl ethyl ketone), toluene, and xylene were detected coincide with the locations where other VOCs have also been found and are to be remediated. Technologies for remediating the other VOCs (i.e., PCE, TCE, DCM) would also be applicable for remediating these constituents. Therefore, no remedial goal will be established for them. 
Removal of the ballast area soil will achieve the ballast area IRAO (i.e., prevent direct contact with pesticide and PCB contaminated soils) and would be readily implemented. SVE in the vadose zone and an asphalt cover over the treatment area will effectively reduce the PCE and TCE concentrations and reduce the potential migration of solvents to the water table. AS/SVE in the groundwater hot spot will effectively reduce concentrations and control migration of VOCs. The asphalt cover system over the treatment area supports both the vadose zone and groundwater hot spot remediation. It is anticipated that the asphalt cover system will remain in place to support the final remedial action.

Although the ballast area will require a Land Use Control Implementation Plan to address residual contamination, this IAPP represents the final decision for the ballast area. However, a final decision for the vadose zone and groundwater hotspot will be documented in the final Record of Decision. The estimated costs of the preferred interim action alternatives are provided in Table 2.

\section{Performance Evaluation}

The AS/SVE interim action treatment system for the pit area subsurface soil (vadose zone) and groundwater hot spot will be evaluated annually. It is anticipated that the AS/SVE system will operate to remediate the vadose zone and groundwater hot spot until the system has completed the remediation or reached the point of diminishing returns.
The point of diminishing returns is the point at which the effectiveness of active remediation is equivalent to the effectiveness of passive remediation. Remediation effectiveness will be determined by evaluating the (1) soil gas concentration, (2) rate of mass removal, (3) system response following restart, and (4) cost of operation. An assessment of these combined criteria will be used to recommend ceasing operations. A monthly extraction load of $1 / 10^{\text {th }}$ of the initial startup monthly extraction load is considered an indication that the system is approaching the point of diminishing returns.

System modifications would consist of active and passive enhancements to the interim action system. Upon completion of the characterization to determine the extent of the plume, an appropriate final strategy for the vadose zone and entire groundwater plume will be developed and the final Record of Decision will be submitted for review and approval consistent with the enclosed schedule (Figure 10).. If the interim action reaches the point of diminishing returns before the migration of contamination to the water table has been eliminated, additional active and/or passive treatment will be documented in the final Record of Decision.

Table 2. Soil and Groundwater Interim Action Preferred Alternatives and Costs

\begin{tabular}{|c|c|c|}
\hline & PREFERRED ALTERNATIVES & COST* \\
\hline Ballast Area & BA-3: Remove the Ballast Area Soils, Dispose Off Site, and Backfill to Grade & $\$ 2,866,000$ \\
\hline Vadose Zone & VZ-2: Conduct Soil Vapor Extraction and Install Asphalt Cover & $\$ 1,143,000$ \\
\hline $\begin{array}{l}\text { Groundwater } \\
\text { Hot Spot }\end{array}$ & GWHS-2: Conduct Air Sparging in Groundwater with Soil Vapor Extraction & $\$ 3,218,000$ \\
\hline
\end{tabular}

*Five year capital, operations and maintenance period 


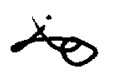

Interim Action Proposed Plan for the CMP Pits Operable Unit (U)

\section{TABLE OF Contents}

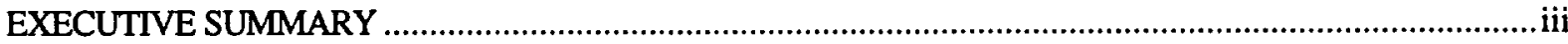

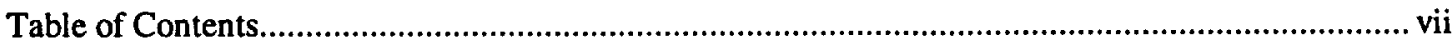

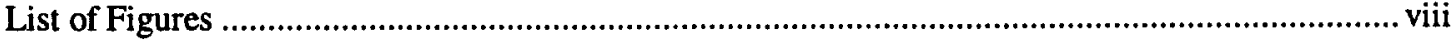

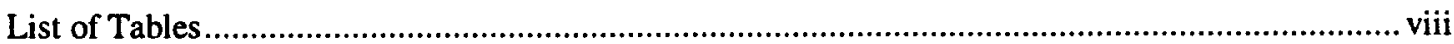

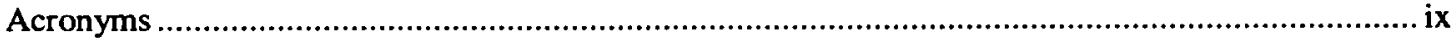

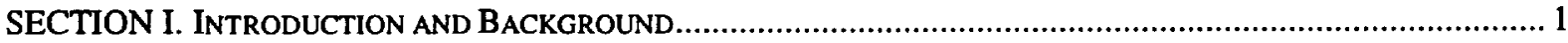

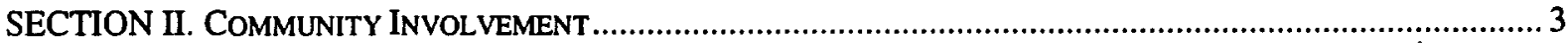

SECTION III. SCOPE AND ROLE OF OPERABLE UNIT (RESPONSE ACTION) WITHIN THE SITE STRATEGY............... 4

SECTION IV MEDIA SPECIFIC OPERABLE UNIT - THE CMP PITS .................................................................. 7

Section IV.A Unit Description, History, and Media Assessment ................................................ 7

Section IV.B Operable Unit Risks ................................................................................... 11

Section IV.C Principal or Low-Level Threat Source Material Review .................................... 16

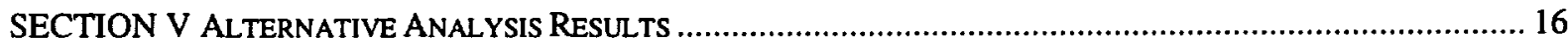

Section V.A Description of Nine Evaluation Criteria ...................................................... 18

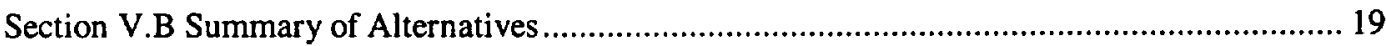

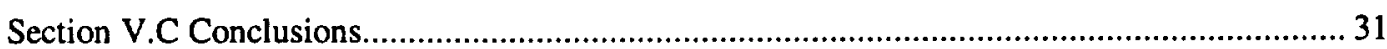

SECTION VI INTEGRATED INTERIM AND FINAL ACTHON IMPLEMENTATION SCHEDULE ...................................33

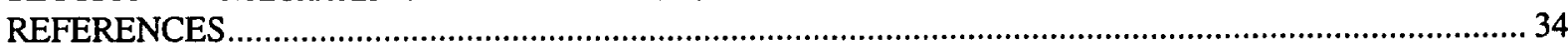

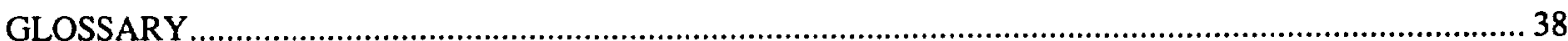




\section{List OF Figures}

Figure 1. Location of the CMP Pits at the Savannah River Site.......................................................................

Figure 2. Location of the CMP Pits within the Pen Branch Watershed............................................................6

Figure 3. Planar View of PCB and Pesticide Contamination at the Ballast Area ...............................................9

Figure 4. Cross-sectional View of the CMP Pits Subsurface (Vadose Zone) Remediation Area ............................. 10

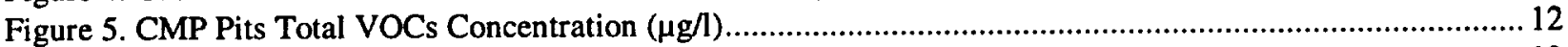

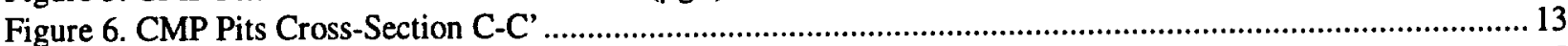

Figure 7. Future Land Use Map of CMP Pits and Surrounding Areas (from FIP Figure 3-3) .............................. 15

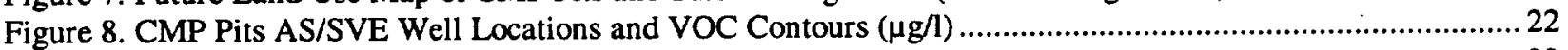

Figure 9. Conceptual CMP Pits Groundwater Hot Spot Remediation System ....................................................2 23

Figure 10. Integrated Interim and Final Action Implementation Schedule .......................................................35

\section{LIST OF TABLES}

Table 1. Summary of Interim Remedial Action Objectives and Remedial Goals for Soil and Groundwater..............v

Table 2. Soil and Groundwater Interim Action Preferred Alternatives and Costs ................................................. vi

Table 3. Maximum Concentrations of Groundwater Constituents and the Corresponding Sampling Locations ........ 8

Table 4. Operable Unit Total Media Risk/Hazard Index..................................................................................... 14

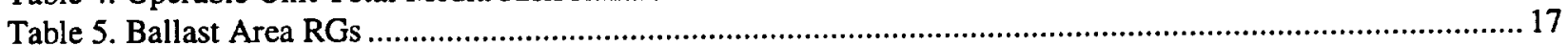

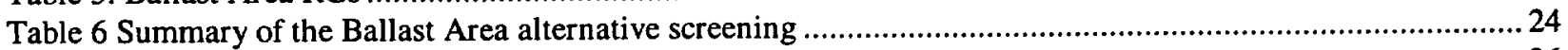

Table 7 Summary of the Vadose Zone alternative screening .........................................................................26

Table 8 Summary of the Groundwater Hot Spot alternative screening............................................................. 28

Table 9. Soil and Groundwater Interim Action Alternatives and Costs ...........................................................30 


\section{ACRONYMS}

\begin{tabular}{|c|c|c|}
\hline ARARs & \multicolumn{2}{|l|}{ Applicable, or Relevant and Appropriate Requirements } \\
\hline AS & \multicolumn{2}{|l|}{ Air Sparging } \\
\hline AS/SVE & \multicolumn{2}{|l|}{ In-Situ Air Sparging/Soil Vapor Extraction } \\
\hline CERCLA & \multicolumn{2}{|l|}{ Comprehensive Environmental Response, Compensation and Liability Act } \\
\hline $\mathrm{cfm}$ & \multicolumn{2}{|l|}{ Cubic feet per minute } \\
\hline CMCOC & \multicolumn{2}{|l|}{ Contaminant Migration Constituent of Concern } \\
\hline CMI/RD/RDR/RA WP & $\begin{array}{l}\text { Corrective Measures Implementation/Remedial Design/Remedial } \\
\text { Report/Remedial Action Work Plan }\end{array}$ & Design \\
\hline CMP Pits & Chemicals, Metals and Pesticides Pits & \\
\hline CMS/FS & Corrective Measures Study/Feasibility Study & \\
\hline $\mathrm{COC}$ & Constituent of Concern & \\
\hline DCM & dichloromethane & \\
\hline ELCR & Excess lifetime cancer risk & \\
\hline FFA & Federal Facility Agreement & \\
\hline gpd & Gallons per day & \\
\hline gpm & Gallons per minute & \\
\hline $\mathrm{HI}$ & Hazard Index & \\
\hline IAPP & Interim Action Proposed Plan & \\
\hline IRAOs & Interim Remedial Action Objectives & \\
\hline IROD & Interim Record of Decision & \\
\hline $1 /$ day & Liters per day & \\
\hline $\mathrm{lb} / \mathrm{yr}$ & Pounds per year & \\
\hline m & Meters & \\
\hline MCL & Maximum Contaminant Level & \\
\hline $\mathrm{NCP}$ & National Oil and Substances Pollution Contingency Plan & \\
\hline NPL & National Priorities List & \\
\hline PCB & Polychlorinated biphenyl & \\
\hline PCE & Tetrachloroethylene & \\
\hline $\mathrm{pCi} / \mathrm{l}$ & Pico Curies per Liter & \\
\hline ppb & Parts per billion & \\
\hline ppm & Parts per million & \\
\hline RAO & Remedial Action Objective & \\
\hline RCRA & Resource Conservation and Recovery Act & \\
\hline RFI/RL/BRA & $\begin{array}{l}\text { RCRA Facility Investigation/Remedial Investigation Report with } \\
\text { Assessment }\end{array}$ & Baseline Risk \\
\hline RG & Remedial Goal & \\
\hline ROD & Record of Decision & \\
\hline SCDHEC & South Carolina Department of Health and Environmental Control & \\
\hline scfm & Standard cubic feet per minute & \\
\hline SCHWMR & South Carolina Hazardous Waste Management Regulations & \\
\hline SRS & Savannah River Site & \\
\hline SVE & Soil Vapor Extraction & \\
\hline TCE & Trichloroethylene & \\
\hline$\mu \mathrm{g} / \mathrm{kg}$ & Microgram per kilogram & \\
\hline$\mu \mathrm{g} / \mathrm{l}$ & Microgram per liter & \\
\hline US DOE & U.S. Department of Energy & \\
\hline US EPA & U.S. Environmental Protection Agency & \\
\hline $\operatorname{VOC}(\mathrm{s})$ & Volatile Organic Compound(s) & \\
\hline WSRC & Westinghouse Savannah River Company & \\
\hline
\end{tabular}




\section{SECTION I. INTRODUCTION AND BACKGROUND}

\section{Location and Operational History}

This Interim Action Proposed Plan (IAPP) is issued by the U.S. Department of Energy (US DOE), which functions as the lead agency for SRS remedial activities, with concurrence by the U.S. Environmental Protection Agency (US EPA) and the South Carolina Department of Health and Environmental Control (SCDHEC). The purpose of this IAPP is to describe the preferred interim remedial action for the Chemicals, Metals, and Pesticides (CMP) Pits and to provide the public with an opportunity to become involved in the decision making process. Figure 1 illustrates the location of the CMP Pits within the Savannah River Site (SRS).

The CMP Pits Operable Unit is comprised of the pit area, ballast area, vadose zone, groundwater hot spot, and distal portion of the groundwater plume (distal plume). This interim remedial action applies to the (1) ballast area (including pit area perimeter surface soil), (2) vadose zone (pit area subsurface soil), and (3) groundwater hot spot. The groundwater hot spot includes the water table in and around the CMP Pits Area within the $1000 \mu \mathrm{g} / \mathrm{l}$ VOC isoconcentration contour. The distal plume is currently under investigation and will be addressed in a later remedial action.

The SRS occupies approximately 310 square miles of land adjacent to the Savannah River, principally in Aiken and Barnwell counties of South Carolina. SRS is owned by the US DOE. Westinghouse Savannah River Company (WSRC) provides management and operating services. SRS has historically produced tritium, plutonium, and other special nuclear materials for national defense. Chemical and radioactive wastes are by-products of nuclear material production processes. Hazardous substances, as defined by CERCLA, are currently present in the environment at SRS.

SRS manages certain waste materials, which are regulated under the Resource Conservation and Recovery Act (RCRA), a comprehensive law requiring responsible management of hazardous waste. RCRA 3004(u) requires that releases from solid waste management units be investigated and remediated as necessary. The CMP Pits are solid waste management units regulated under RCRA 3004(u).
Compliance History and Objective of IAPP On December 21, 1989, SRS was included on the National Priorities List (NPL). This inclusion created a need to integrate the established RCRA Facility Investigation (RFI) Program with Comprehensive Environmental Response, Compensation and Liability Act (CERCLA) requirements to provide for a focused environmental program. In accordance with Section 120 of CERCLA, US DOE has negotiated a Federal Facility Agreement (FFA) (FFA 1993) with US EPA and SCDHEC to coordinate remedial activities at SRS as one comprehensive strategy that fulfills these dual regulatory requirements.

Both RCRA and CERCLA require that the public be given an opportunity to review and comment on a draft permit modification and a proposed remedial alternative. Public participation requirements are listed in South Carolina Hazardous Waste Management Regulations (SCHWMR) R.61-79.124 and Sections 113 and 117 of CERCLA. These requirements include establishment of an administrative record file that documents the selection of remedial alternatives and allows for review and comment by the public regarding those alternatives (see Section II). The Administrative Record File must be established at or near the facility at issue. The SRS Public Involvement Plan (DOE 1994) is designed to facilitate public involvement in the decision-making process for permitting, closure, and selection of remedial alternatives.

SCHWMR R.61-79.124 and Section 117(a) of CERCLA, as amended, require advertisement of the draft permit modification and any proposed remedial or interim action and requires an opportunity for the public to participate in the selection of a remedial or interim action. Because this is an interim remedial action, a permit modification is not required for this IAPP. A final permit modification will (1) include the final selection of remedial alternatives under RCRA, (2) be sought for the entire CMP Pits with the final Statement of Basis/Proposed Plan and (3) will include the necessary public involvement and regulatory approvals. This IAPP satisfies the RCRA requirements for an Interim Measures Workplan. 


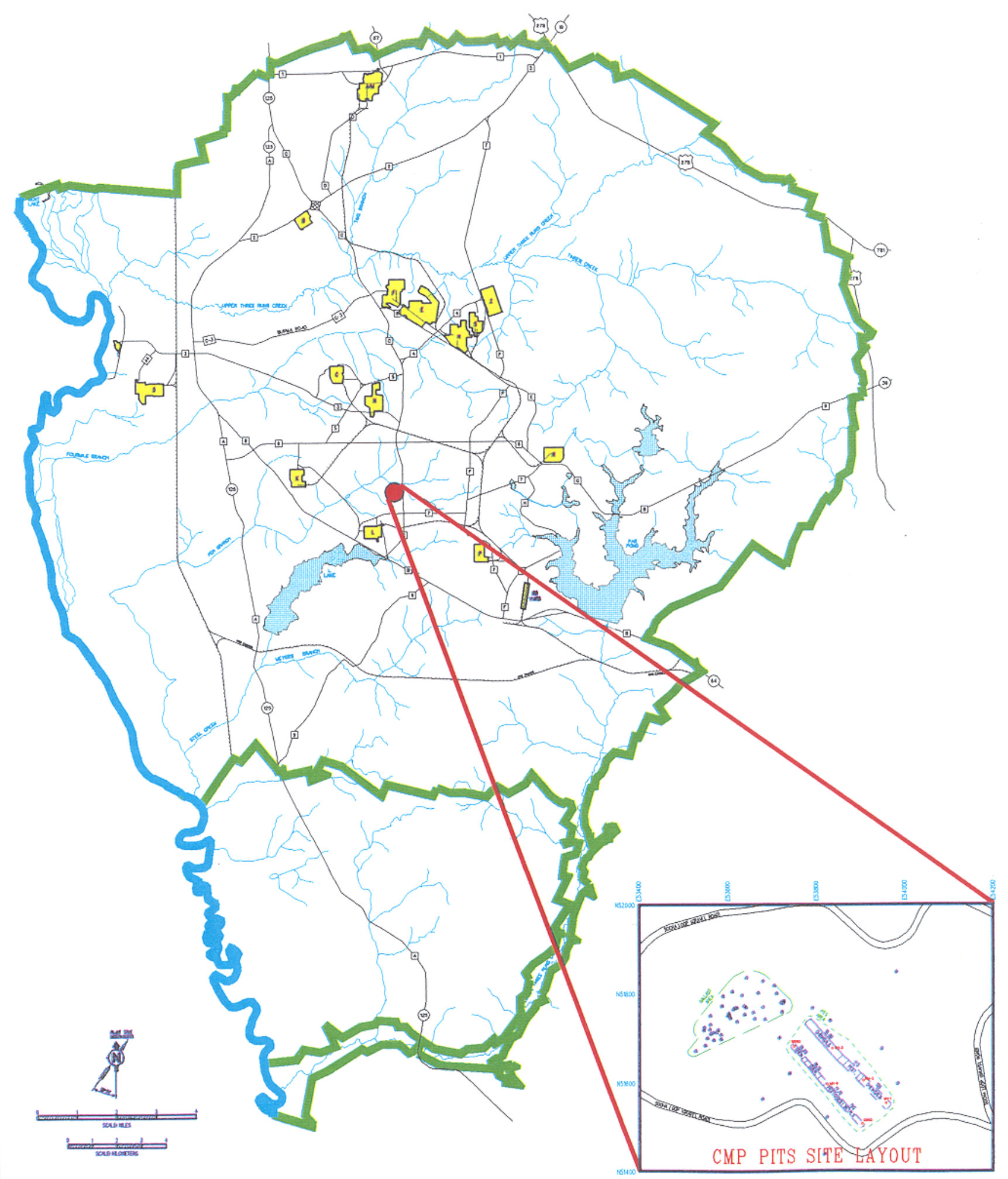


This IAPP summarizes the documents in the administrative record file and presents several interim alternatives as well as the rationale for selecting a preferred alternative. To gain a better understanding of RCRA and CERCLA activities as they pertain to the CMP Pits, the public is encouraged to review this file. This IAPP seeks comment on the delisting of the decontamination fluid for each alternative for which delisting is proposed. Delisting of the decontamination fluid will be in accordance with Superfund guidance in OSWER directives 9234.2-01/FS-A and 9347.3-09FS. Refer to Section II of this document for information regarding availability, access, and community participation.

The interim remedial alternatives that will satisfy the FFA requirements will be selected by US DOE, in consultation with US EPA and SCDHEC, only after the public comment period has ended and all comments submitted have been reviewed and considered. A Responsiveness Summary will be prepared to address significant comments raised during the public comment period. The summary will be made available with the interim Record of Decision (IROD). It is important to note that the final interim action(s) may differ from the preferred interim alternatives discussed in this plan, depending on new information or public comments.

The interim alternative chosen will be protective of human health and the environment and will comply with all federal and state environmental laws. A final Record of Decision (ROD) will follow additional study by SRS, regulator approval, and public involvement, and will document the final CERCLA decision for the unit.

\section{SECTION II. CoMmunity INVOLVEMENT}

This document summarizes information provided in the FFA administrative record file, which is available for review by the public at the following locations:

\section{U. S. Department of Energy}

Public Reading Room

Gregg-Graniteville Library

University of South Carolina-Aiken

171 University Parkway

Aiken, SC 29801

(803) 641-3465
Thomas Cooper Library

Government Documents Department

University of South Carolina

Columbia, SC 29208

(803) $777-4866$

Similar information is available through the repositories listed below:

Reese Library

Augusta State University

2500 Walton Way

Augusta, GA 30910

(706) 737-1744

Asa H. Gordon Library

Savannah State College

Thompkins Road

Savannah, GA 31404

(912) 356-2183

The RCRA Administrative Record File for SCDHEC is available for review by the public at the following locations:

The South Carolina Department of Health and Environmental Control

Bureau of Land and Waste Management

8901 Farrow Road

Columbia, South Carolina 29203

(803) 896-4000

Lower Savannah District Environmental Quality Control Office

215 Beaufort Street, Northeast

Aiken, South Carolina 29802

(803) 648-9561

The public will be notified of a public comment period through the SRS Environmental Bulletin, a newsletter sent to citizens in South Carolina and Georgia, through notices in the Aiken Standard, the Allendale Citizen Leader, the Barnwell People Sentinel, The State, and the Augusta Chronicle newspapers, and through announcements on local radio stations. 
US DOE will provide an opportunity for a public meeting during the public comment period if interest is expressed. The public will be notified of the date, time, and location. At the meeting, the proposed interim action will be discussed and questions about the action will be answered. To request a public meeting during the public comment period, to obtain more information concerning this plan, or to submit written comments, contact:

Jim Moore

Public Involvement

Westinghouse Savannah River Company

Savannah River Site

Building 742A

Aiken, SC 29808

$1(800) 249-8155$

Following the public comment period an Interim Record of Decision (IROD) will be signed. The IROD will detail the interim remedial alternative(s) chosen and will include responses to oral and written comments received during the public comment period in the Responsiveness Summary.

\section{SECTION III. Scope AND Role of OPERable UNIT (Response ACtion) Within the Site STRATEGY}

The overall strategy for addressing the CMP Pits is to (1) perform an RFI/RI to identify the nature and extent of contamination and the media of concern; (2) perform a baseline risk assessment (BRA) to evaluate media of concern, COCs, exposure pathways and potential risks; (3) evaluate the possible interim remedial alternatives and acquire community involvement in the remedial selection and document the process in the Interim Action Proposed Plan (IAPP), (4) evaluate and perform an interim action to remediate, as needed the identified media, (5) evaluate the possible remedial alternatives and acquire community involvement in the remedial selection and document the process in the Corrective Measures Study/Feasibility Study (CMS/FS) and Proposed Plan (PP); and (6) evaluate and perform a final action to remediate, as needed, the identified media.

For the ballast area, this document represents the final decision for all response action to be taken. For the vadose zone and groundwater hot spot, this document is an interim action and does not represent a final decision.
Remediation of the CMP Pits will proceed with an approach consistent with the US EPA guidance document Presumptive Response Strategy and ExSitu Treatment Technologies for Contaminated Ground Water CERCLA Sites (EPA 1996). The interim action will focus on remediation of the (1) CMP Pits area subsurface soil (vadose zone), (2) groundwater hot spot, and (3) ballast area surface soils (including pit area perimeter surface soils). The interim action is intended to prevent further migration of the highest VOC concentrations in the groundwater, prevent further migration of contaminants from the source, and remove the contaminants in the ballast area to prevent industrial worker and ecological exposure to the ballast area surface soil. In addition, the interim action will provide additional site characterization data.

The AS/SVE interim action treatment system for vadose zone and groundwater hot spot will be evaluated annually. Performance reviews will be conducted during the interim action to make modifications to design parameters, well locations, injection processes, etc. Data gathered from the installation of additional monitoring wells at the CMP Pits will also be used to assist in the remediation process refinement. It is anticipated that the Air Sparging/Soil Vapor Extraction (AS/SVE) system will operate to remediate the vadose zone and groundwater hot spot until the system has completed the remediation or reached the point of diminishing returns.

The point of diminishing returns is the point at which the effectiveness of active remediation is equivalent to the effectiveness of passive remediation. Remediation effectiveness will be determined by evaluating the (1) soil gas concentration, (2) rate of mass removal, (3) system response following restart, and (4) cost of operation. An assessment of these combined criteria will be used to recommend ceasing operations. A monthly extraction load of $1 / 10^{\text {th }}$ of the initial startup monthly extraction load is considered an indication that the system is approaching the point of diminishing returns. System modifications would consist of active and passive enhancements to the Interim Action system. Upon completion of the characterization to determine the extent of the plume, an appropriate final strategy for the vadose zone and groundwater hot spot will be developed and the final Record of Decision will be submitted for review and approval consistent with the enclosed schedule (Figure 10). 
The CMP Pits, along with several other waste units, are located within the Pen Branch Watershed. (Figure 2) Several operable units within this watershed will be evaluated to determine impacts to associated streams and wetlands. SRS will manage all operable units to minimize impact to the Pen Branch watershed. This proposed interim action for the CMP Pits is not a final action but is proposed to minimize the impact of the CMP Pits on the Pen Branch watershed. Upon agreement between the US DOE, US EPA, and SCDHEC, on the disposition of all operable units within this watershed, a final comprehensive Record of Decision (ROD) for the watershed will be pursued with further public involvement.

Due to the complexity of the distal plume and the current uncertainties with the hydrogeology, further characterization will be conducted concurrently with this interim action. The characterization results associated with the distal plume will be included in the CMS/FS and will support the pursuit of a final remedial action. 
Figure 2. Losation of the CMP Pits within the Pen Branch Watershied

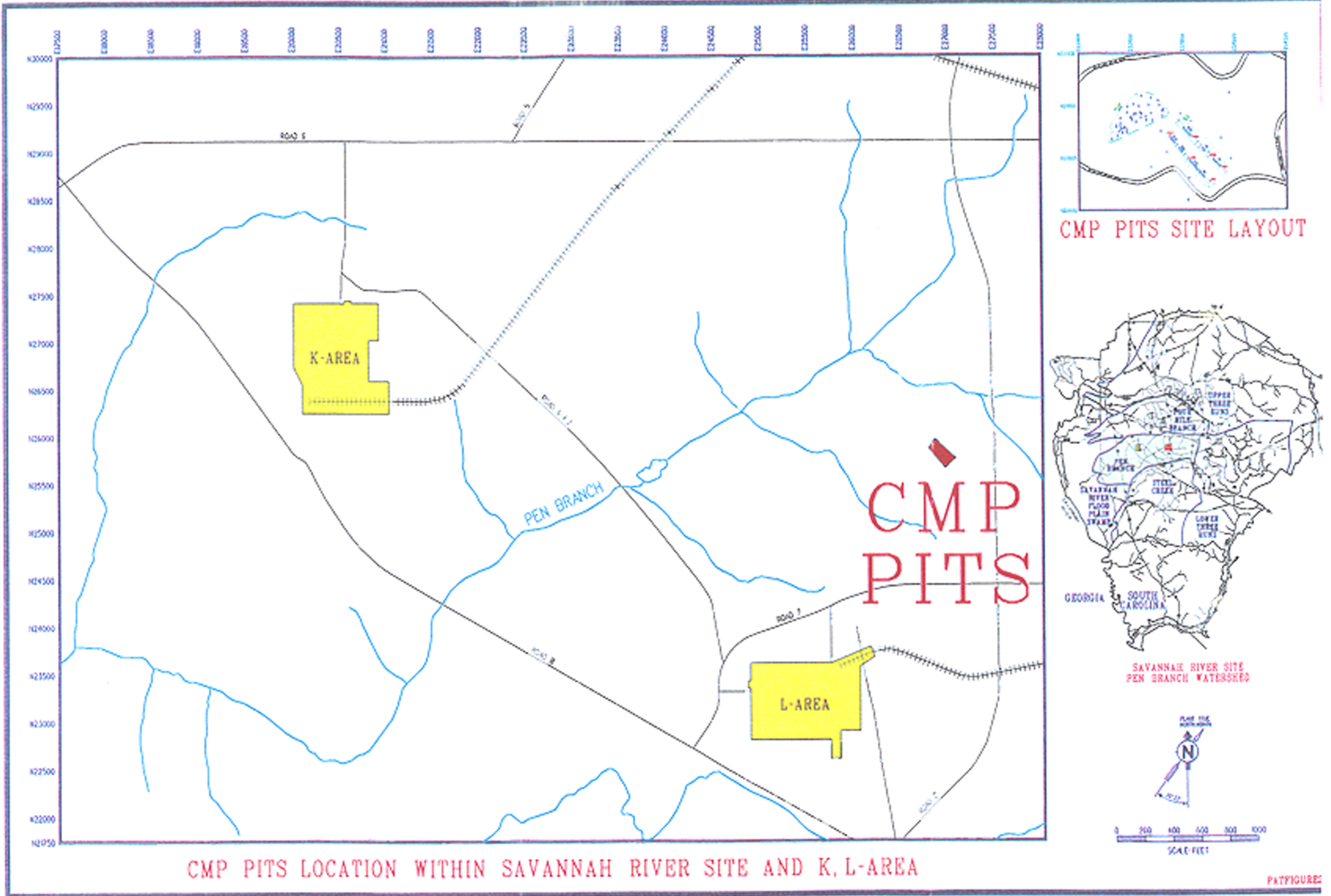


SECTION IV MEdia Specific Operable UNIT THE CMP PTTS

\section{Section IV.A Unit Description, History, and Media Assessment}

\section{Unit Description and Location}

The CMP Pits are located in the central portion of the SRS in Barnwell County. They are approximately 5,200 feet north of the L-Area perimeter fence. The Pen Branch stream is located approximately 1,250 feet north of the unit (Figure 2). The unit consists of seven unlined pits, placed in two rows, that formerly occupied the top of a knoll at an approximate elevation of 310 feet above mean sea level. The pits are 10 to 15 feet wide, 45 to 70 feet long, and 10 to 15 feet deep. The ballast area is located at the northern edge of the knoll and extends down the side slope of the knoll for a distance of 20 to 30 feet.

\section{Unit History}

The CMP Pits were placed in operation in August 1971. Formal disposal records were not maintained so the volume and content of the wastes disposed in some of the pits were not recorded. The pits were designated to receive pesticides, chemicals and metals. There is evidence that fluorescent light ballasts containing polychlorinated biphenyls (PCBs) were disposed during April 1979. These ballast systems were typically filled with heat transfer oil, which provided thermal insulation and a heat dissipation capability. The heat transfer oils typically contained PCBs. Partial disposal records for these pits indicate disposal of trichloroethylene (TCE), tetrachloroethylene (PCE), lighting ballasts and pesticides. These pits were backfilled and closed in December 1979.

\section{CMP Pits Early Action}

SRS initiated a remedial action in 1984 with the concurrence of SCDHEC and excavated the contents of all of the pits. Two trenches were excavated along the axis of the pits. Pesticides and drums of buried chemicals were removed. Contaminated soil was excavated until total VOCs were less than 100 parts per million (ppm) and pesticide concentrations were less than $25 \mathrm{ppm}$. However, elevated levels of some constituents remain at the CMP Pits.

Soil, drums and other containers which were managed consistent with current regulations, were subsequently identified as RCRA listed wastes (F, D, $P$ and $U$ codes). This material was placed in metal boxes and stored in the appropriate permitted hazardous waste storage facility located on Savannah River Site.

Backfilling activities were initiated following excavation and soil sampling. The base of the trenches were lined with $\mathrm{Typar}^{\mathrm{TM}}$ filter fabric with crushed aggregate. Seven manholes, 6 feet in diameter, were installed on beds of compacted aggregate 6-inches thick. An infiltration blanket was covered with a layer of Typar ${ }^{\mathrm{TM}}$ filter fabric. This system was installed to allow for venting of soil.

The pits were then backfilled with clean soil that was compacted to approximately 4 feet below the existing ground surface. A low infiltration cap consisting of 80-mil high density polyethylene was installed and covered with 3.5 feet of clean soil fill and 1 foot of topsoil. A 1 to 2 foot drainage ditch outside of the capped area was excavated around the entire site and lined with gravel. Following completion of the drainage ditch, the site was seeded.

The CMP Pits early closure was not formally performed under any regulatory program; however, SCDHEC inspections occurred routinely throughout the entire closure. The unit was identified as a RCRA/CERCLA unit in 1989.

\section{Ballast Area}

The ballast area originally contained lighting ballasts which were removed during the characterization activities in 1995. The contamination in this area is thought to be related to the 1984 drum and soil removal at the pits. Specifically, it is believed that the soil contamination relates directly to excavated soils that were misapplied to this area as if it were clean fill. The lighting ballasts observed at or near the surface were removed from the area and disposed of as potential PCB-contaminated waste material in keeping with all applicable federal, state and local government regulations and guidelines.

In 1996 a maintenance activity was undertaken by SRS in the ballast area to minimize erosion of surface soil by stormwater runoff. Approximately 6 inches of clean soil was spread over the entire ballast area, perimeter drainage was channeled to downslope to drainage pipes placed in the former gullies, and erosion control stabilization measures (riprap, reseeding, and erosion protection fabric) were applied to the ground surface. 


\section{Media Assessment}

The RCRA Facility Investigation/Remedial Investigation Report with Baseline Risk Assessment for the Chemicals, Metals, and Pesticides Pits $(U)$ (WSRC, 1997) contains detailed analytical data for all of the environmental media samples taken in the characterization of this operable unit. During the RFI/RI, the following areas were investigated at the CMP Pits waste unit:

- Ballast Area surface soil,

- Vadose Zone (CMP Pits Area subsurface soil depths up to and greater than 4 feet beneath the base of the pit and perimeter soil),

- Upper Three Runs groundwater aquifers.

\section{Surface Soil}

Analytical data collected for the RFI/RI indicate that impact to the soil media associated with the ballast area and vadose zone has occurred from chemical contaminants (i.e., pesticides, PCBs, and VOCs). Pesticides are the most prevalent constituents at the ballast area. The samples indicate that the pesticides are grouped in the center of the ballast area. Only one PCB, Aroclor-1248, was detected at the ballast area. Approximately 1300 cubic yards of soil is contaminated with pesticides. Of the 1300 cubic yards, 300 cubic yards are also contaminated with PCBs (Aroclor-1248). Figure 3 illustrates the relative extent of the $\mathrm{PCB}$ and pesticide contamination exceeding the RGs in the ballast area.

\section{Subsurface Soil}

High concentrations of VOCs (principally PCE) have been identified in the vadose zone under the original chemical pits (18.3G and 18.1G). Lateral extent of contamination within the vadose zone is confined to the boundary of the two original chemical pits while the vertical extent reaches to the water table. Therefore, these two pits are the probable source of groundwater contamination. Figure 4 illustrates the relative extent of the VOC contamination in the vadose zone.

\section{Groundwater}

The tan clay confining zone divides the Upper Three Runs Aquifer at the CMP Pits into the upper water table and the lower water table. The depth to the water table in the area of the CMP Pits varies from 80 to more than 100 feet below ground surface. The saturated thickness of the upper water table varies from 5 to 23 feet across the area.

The upper water table is contaminated with acetone, DCM, PCE, toluene, TCE, and xylene. The principal contaminant is PCE. The location of the contaminants in groundwater follows the general groundwater flow direction. Concentrations of DCM, PCE, and TCE in the upper water table exceed Safe Drinking Water Act MCLs (Table 3). Concentrations of PCE and TCE are up to 500 times greater in the upper water table than in the lower water table. Since the concentrations in the lower water table are only two times MCL, remediation of the lower water table will be addressed as part of the final remedial action. This indicates that contamination is not migrating readily below the tan clay confining layer.

Table 3. Maximum Concentrations of Groundwater Constituents and the Corresponding Sampling Locations

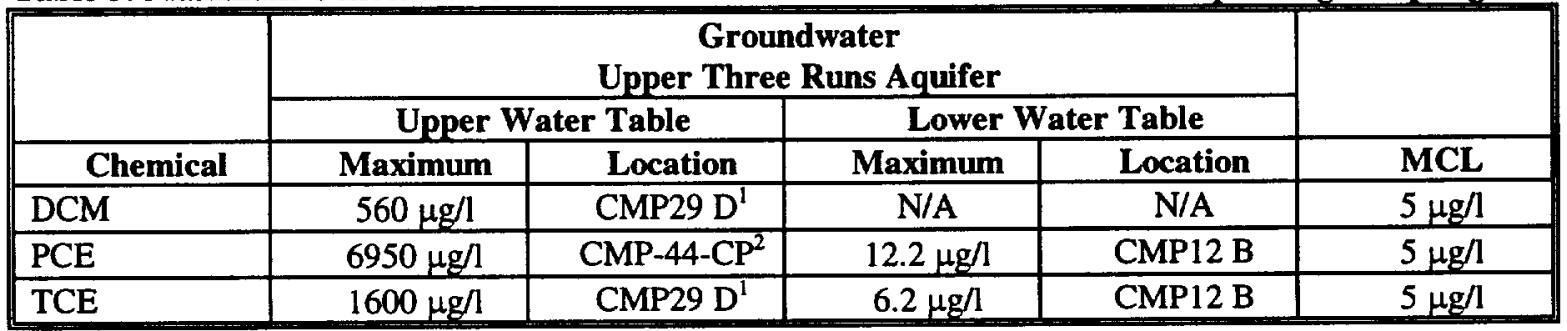

1 - CMP29 D is a temporary piezometer (hydropunch) sample.

2 - CMP-44-CP is a CPT sample.

DCM dichloromethane

MCL Maximum Contaminant Level

N/A Not Applicable

PCE tetrachloroethylene

TCE trichloroethylene 


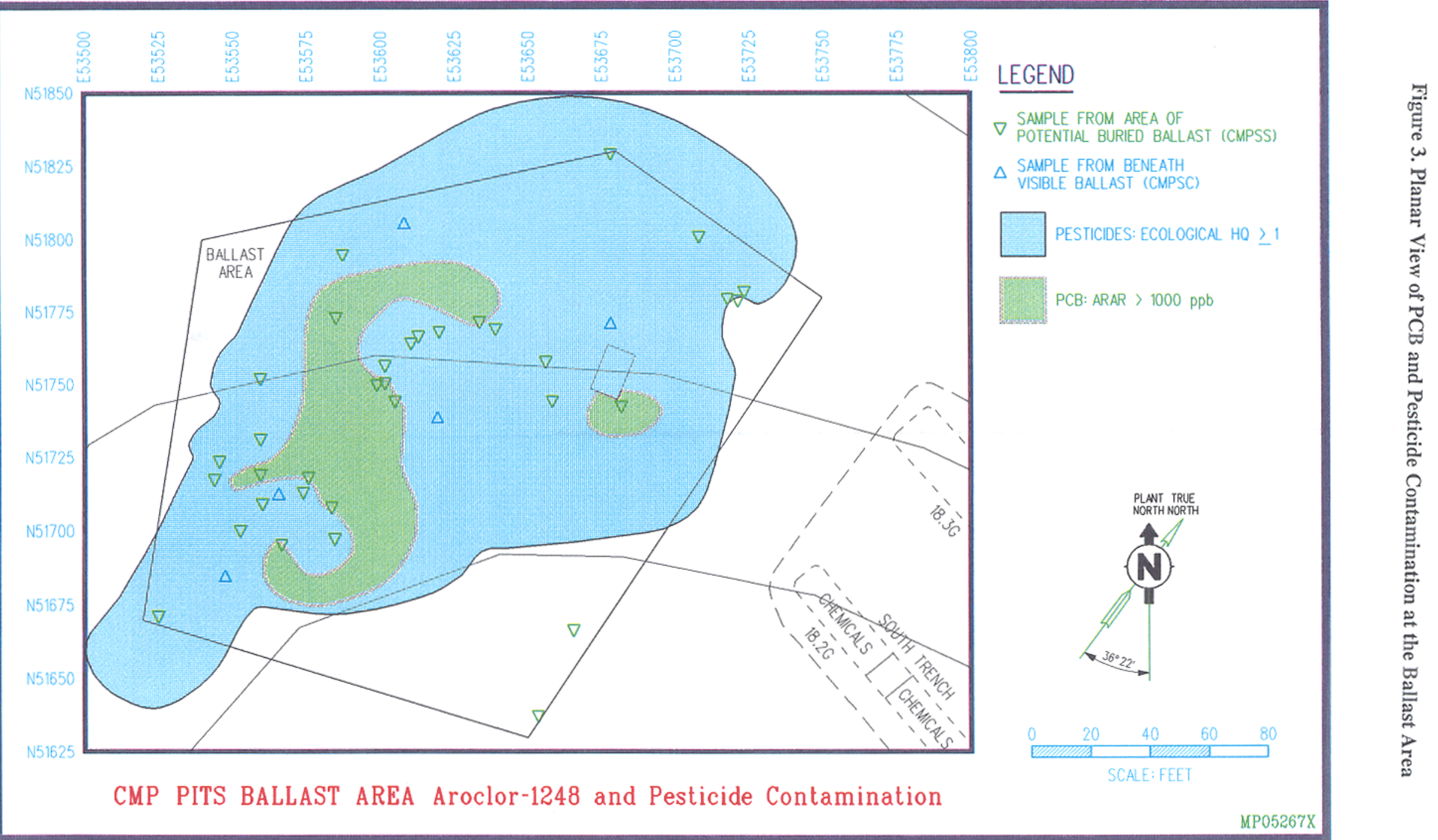


Figure 4. Cross-sectional View of the CMP Pits Subsurface (Vadose Zone) Remediation Area

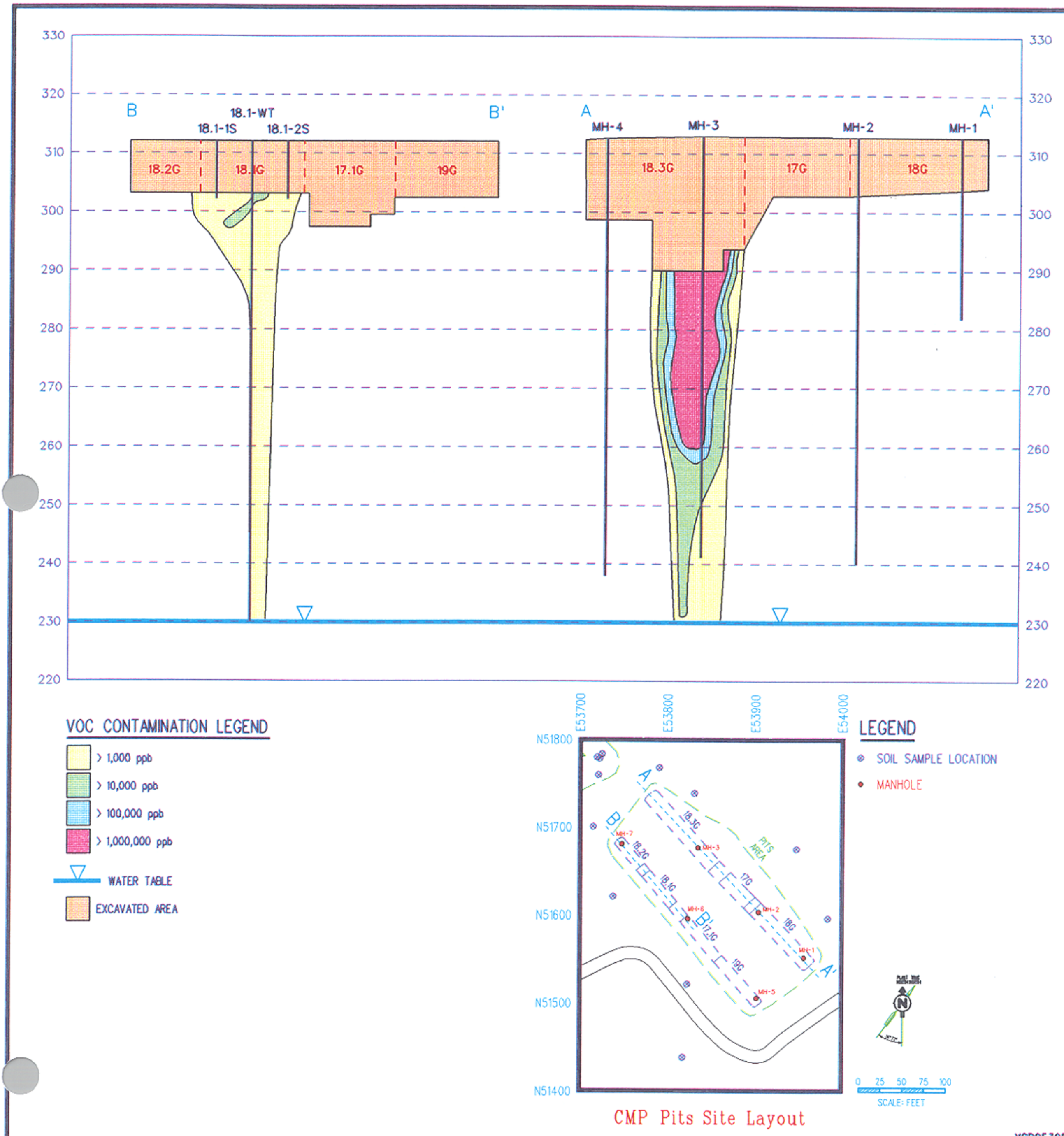


The groundwater hot spot beneath and adjacent to the CMP Pits area is defined by VOC contamination in excess of $1,000 \mu \mathrm{g} / \mathrm{l}$. Figures 5 and 6 illustrate the known extent of the hot spot and its general configuration. The shape and migration behavior of the hot spot appears to be significantly affected by an area of lower permeability (and subsequent lower VOC concentration) to the north of the pit area. Specifically, the geometry of the hot spot suggests that it is migrating to the northeast and northwest around the low permeability area, from the vadose zone source towards Pen Branch

\section{Soil Leachability Analysis}

The results of the contaminant fate and transport analysis and monitoring indicate that VOCs have been leaching from the contaminated soil into the groundwater beneath the CMP Pits.

The VOCs (e.g., DCM, PCE, and TCE) have high concentrations in soil and are expected to produce leachate. Acetone, methyl ethyl ketone, toluene, and xylene are not addressed as CMCOCs in the subsurface soils since they were detected in the same area where DCM, TCE, and PCE were found. Remediation methods for DCM, TCE, and PCE, are also applicable for acetone, methyl ethyl ketone, toluene, and xylene.

\section{Section IV.B Operable Unit Risks}

As part of the investigation/assessment process for the CMP Pits, a BRA was performed using the data generated during the assessment phase. Detailed information regarding the risk assessment can be found in the RCRA Facility Investigation/Remedial Investigation Report with Baseline Risk Assessment for the Chemicals, Metals, and Pesticides Pits (U) (WSRC, 1997). The results of the BRA identify the COCs and characterize the associated risks to both human health and the environment.

\section{Human Health Risk Assessment}

The human health risk assessment considered both current and future land uses and the individuals who are likely to be exposed. US EPA methods were used to conduct the risk assessment. Risks were quantified for adverse noncancer and cancer effects.

\section{Current Land Use}

\section{Ballast Area}

- The chemical cancer risk to the current worker is associated with ingestion of soil and dermal contact with $\mathrm{p}^{\prime}, \mathrm{p}^{\prime}$-DDT in the soil.
Future Land Use

Ballast Area

- The chemical noncancer hazard for the hypothetical future resident (adult/child) is associated with the uptake of $\mathrm{p}^{\prime}, \mathrm{p}^{\prime}$-DDT and dieldrin from the soil into the produce plants (i.e., produce ingestion).

- The chemical cancer risk for the hypothetical future resident (adult/child) is primarily associated with the uptake of Aroclor-1248, $\mathbf{p}^{\prime}, \mathrm{p}^{\prime}$-DDT and dieldrin from produce ingestion.

- The chemical cancer risk for the hypothetical future industrial worker is associated with ingestion of, and dermal contact with Aroclor$1248, \mathrm{p}^{\prime}, \mathrm{p}^{\prime}$-DDT and dieldrin in soil.

Pits Area

- The chemical noncancer hazard for the hypothetical future resident (adult/child) is primarily associated with the uptake of arsenic, $\mathrm{p}^{\prime}, \mathrm{p}^{\prime}$-DDT, and dieldrin from produce ingestion.

- The chemical cancer risk for the hypothetical future resident (adult/child) is primarily associated with the uptake of arsenic and dieldrin from produce ingestion.

- The chemical cancer risk for the hypothetical future industrial worker is associated with ingestion of produce and dermal contact with aldrin, $\mathbf{p}^{\prime}, \mathrm{p}^{\prime}$-DDT and dieldrin in soil.

\section{Groundwater}

- The chemical cancer risk for the future resident (child/adult) and for future industrial worker is associated with the DCM, TCE and PCE.

\section{Ecological Risk Assessment}

The baseline ecological risk assessment defined the likelihood of harmful effects or the risk to ecological receptors from exposure to contaminants at the CMP Pits. Receptors include both terrestrial plants and animals and their habitats. 
Figure 5. CMP Pits Total vOCs Concentration $(\mu 2 /)$

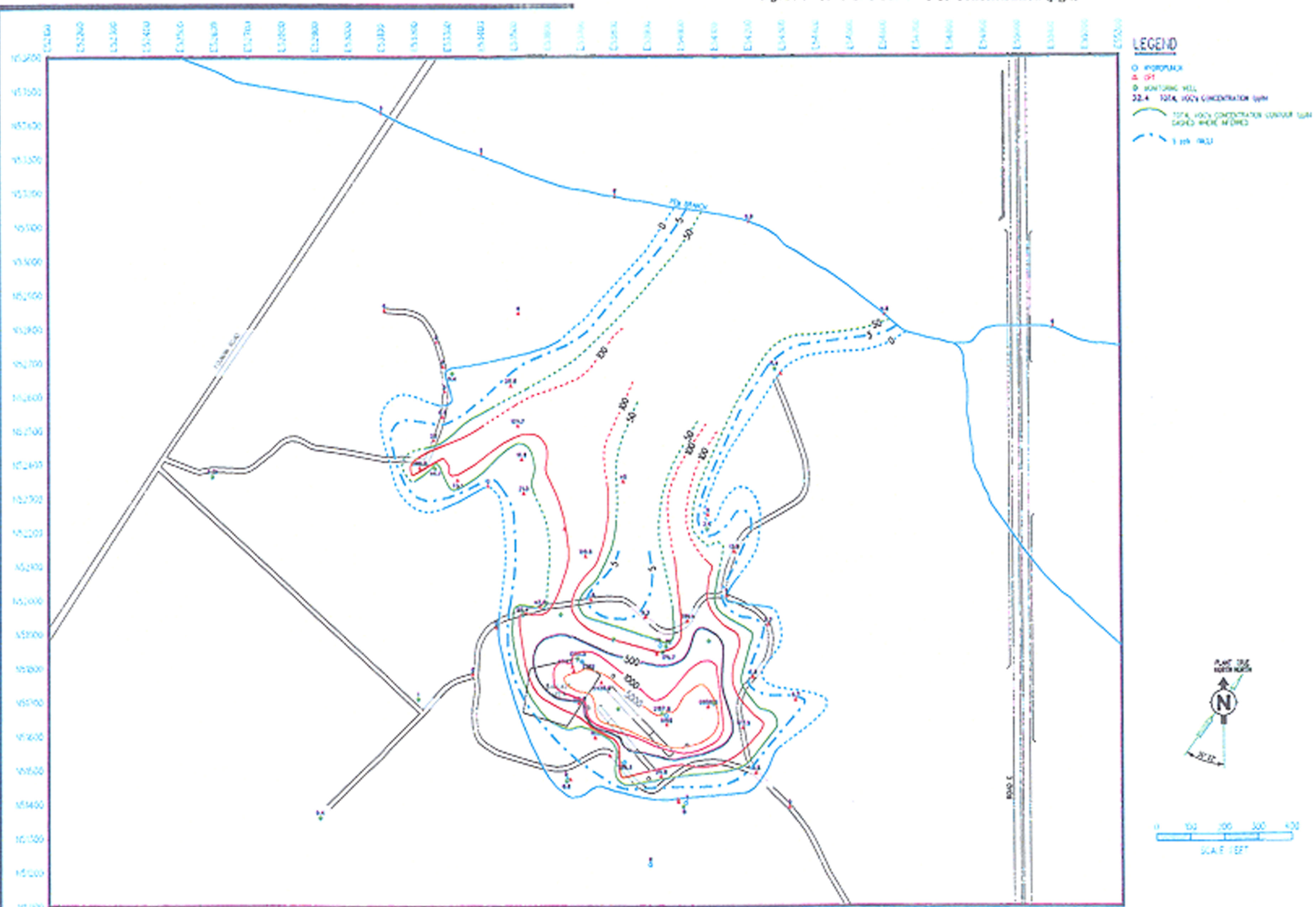

CMP PITS TOTAL VOC'S CONCENTRATION (ppb) 


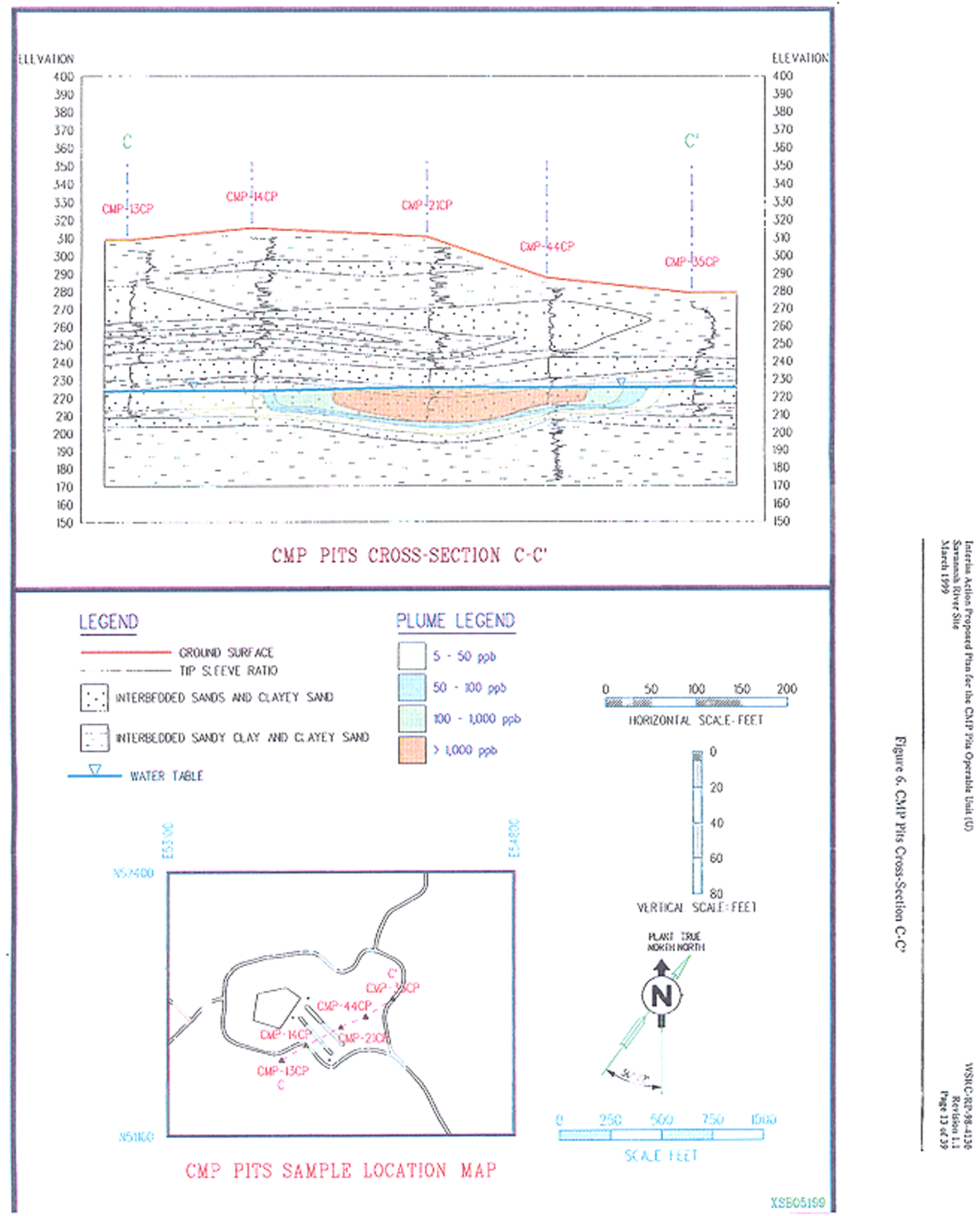


The results of the ecological risk assessment identified risks to terrestrial receptors from metals, pesticides, and PCBs in the ballast area. The highest risks from metals are those for vegetation, earthworms, and shrews because they are exposed more directly to soil. Metals pose a risk to vegetation, earthworms, and shrews at the ballast area. Aroclor- 1248 and pesticides pose risk to shrews and wrens at the ballast area.

\section{Risk Assessment Summary}

Table 4 provides a summary of the total media risk/hazard index and total cumulative risk for each exposure group for the various land uses.

- There are no primary soil COCs identified for the industrial worker.

- The ballast area has been shown to have potential produce ingestion risks above $1 \times 10^{-4}$ for the hypothetical future resident.

- The vadose zone poses a threat to groundwater quality because of potential leaching from soil to groundwater, resulting in groundwater concentrations exceeding MCLs. Primary contributors to this pathway are VOCs (i.e., DCM, PCE, and TCE). These constituents have been identified as the only CMCOCs in the soil.

- The final ecological COCs in soil are DDD, DDE, DDT and dieldrin, endrin, and Aroclor1248 at the ballast area. These COCs may impact the environment for both soil-dwelling and nonsoil-dwelling ecological receptors.

- Due to the nature of the soil contamination, it is anticipated that the CMP Pits area will be a limited-use area with restrictions. Although the CMP Pits Area is located outside of an Industrial use zone defined by Figure 3-3 of the FFA Implementation Plan, recommended RGs are based upon being protective of the industrial worker. Figure 7 illustrates the relationship between the CMP Pits area and the other reactor areas designated as future heavy industrial (nuclear) areas.

Table 4. Operable Unit Total Media Risk/Hazard Index

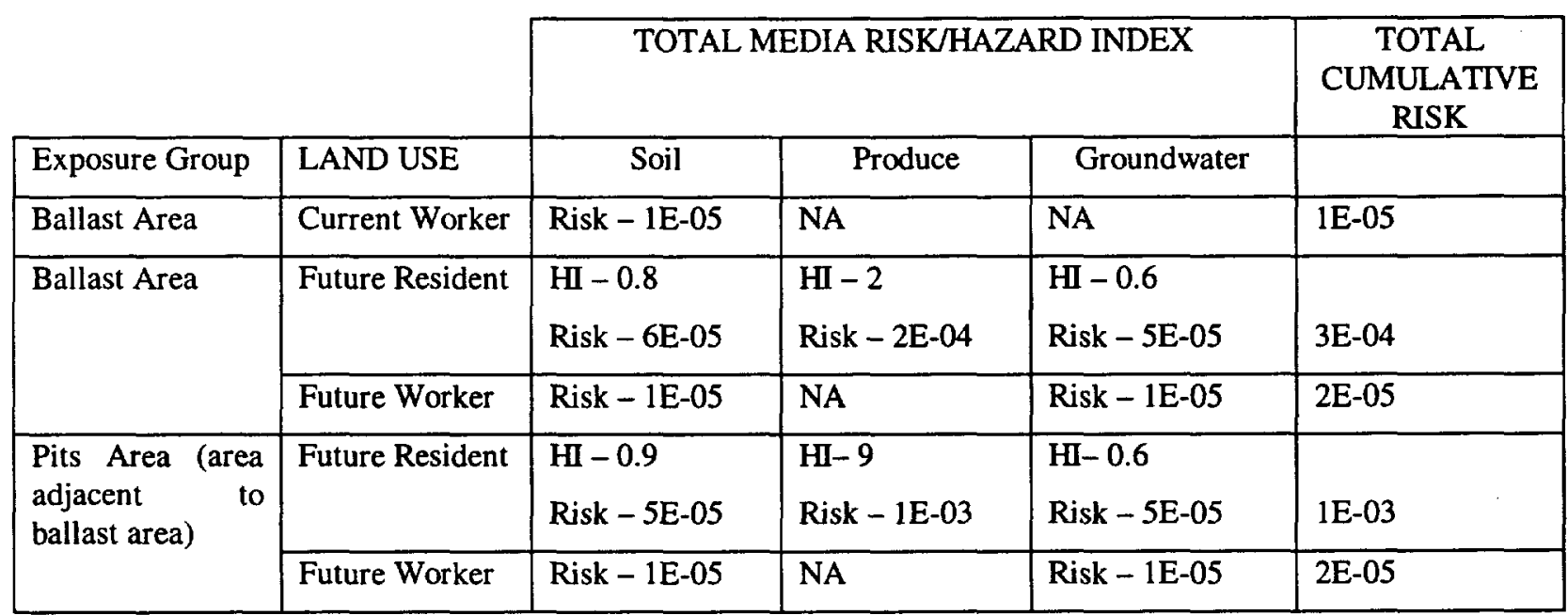



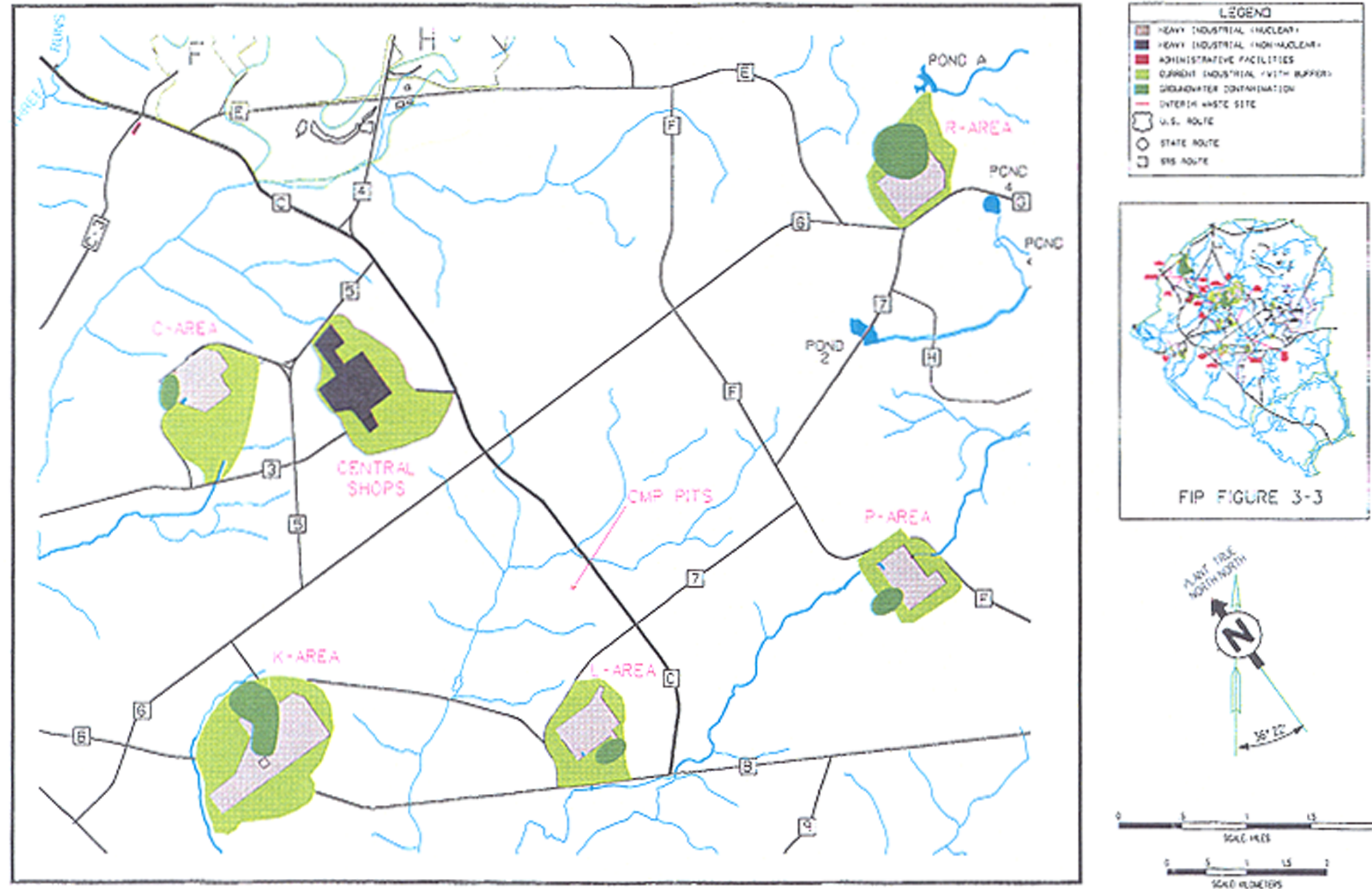

FIP F'GLRE $3-3$

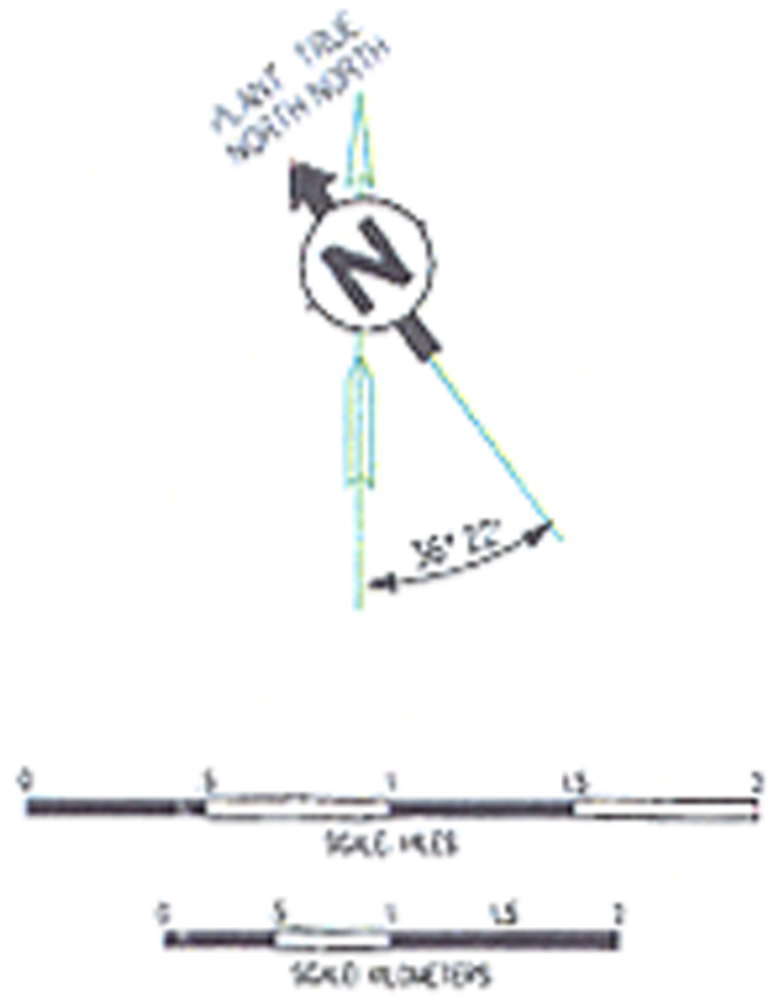

FUTURE LAND USE MAP OF CMP PITS AND SURROUNDING AREA (From FIP Figurc 3-3) 
Table 5 lists proposed RGs (chemical concentrations associated with levels of risk) for ballast area soils and the justification for selection of an industrial scenario for human health risks. The PCB RG is based upon promulgated cleanup standards. The heptachlor RG is based upon human health $10^{-6}$ risks (industrial worker), and the remaining pesticides RGs are based upon ecological risks.

\section{Section IV.C Principal or Low-Level Threat Source Material Review}

An Interim Remedial Action for the CMP Pits is recommended based upon the RFI/RI/BRA. Although all source materials (drums, lighting ballast, etc.) were removed as part of the 1984 CMP Pits Early Action and in 1995 as part of the characterization activities, contaminated media remains in the vadose zone and groundwater. A review of the contamination present within the soils and groundwater at the CMP Pits indicates that the wastes represent principal source threats due to the high concentrations of contaminants. The ballast area, vadose zone and groundwater hot spot contamination can be categorized as follows:

- High concentrations of PCB (Aroclor-1248) and Pesticide (DDD, DDE, and DDT) represent a principal source threat in the ballast area. Maximum concentrations of Aroclor-1248 $(15,300 \mu \mathrm{g} / \mathrm{kg}), \quad$ DDD $(1870 \mu \mathrm{g} / \mathrm{kg}), \quad$ DDE $(1,340 \mu \mathrm{g} / \mathrm{kg})$, and DDT $(115,000 \mu \mathrm{g} / \mathrm{kg})$ exceed the recommended RGs (Table 5).

- High concentrations of DCM $(296,000 \mu \mathrm{g} / \mathrm{kg})$, PCE $(6,980,000 \mu \mathrm{g} / \mathrm{kg})$, and TCE $(31,000 \mu \mathrm{g} / \mathrm{kg})$ in the vadose zone represent a principal source threat.

- High concentrations of DCM $(560 \mu \mathrm{g} / \mathrm{l}), \mathrm{PCE}$ $(6950 \mu \mathrm{g} / \mathrm{l})$ and TCE $(1600 \mu \mathrm{g} / \mathrm{l})$ in the aquifer sediments within the groundwater hot spot area represent a principal source threat.

The action suggested in this IAPP is consistent with a bias for treatment of principal source threat materials because:

- treatment technologies are feasible and available in a reasonable time frame

- the volume and complexity of the site make implementation technically and economically practicable
- implementation will not result in severe effects across environmental media

\section{SECTION V Alternative ANALysis Results}

Based on the RFI/RI and the BRA, a final remedial action objective (RAO) can be established for the ballast area and interim RAOs (IRAOs) can be established for the vadose zone and groundwater hot spot. The final and interim RAOs are specific goals developed to reduce risk to human health and the environment. The final and interim RAOs established for this IAPP are listed below.

\section{Ballast Area}

- Prevent direct contact with PCB and pesticides contaminated surface soils, such that the contaminants of concern are not a continued significant risk to human health or the ecology.

Vadose Zone

- Treat the vadose zone soils beneath the pits where the combined PCE and TCE concentrations exceed $2,000 \mu \mathrm{g} / \mathrm{kg}$, with active treatment techniques as long as effective, with an overall objective to reduce the potential migration of solvents to the water table that result in contamination concentrations exceeding the MCL.

- Continue to provide infiltration control with a cover system in the vadose zone treatment area, to reduce the potential migration of solvents from the vadose zone to the water table.

\section{Groundwater Hot Spot}

- Treat the water table in the vicinity of the pits, within the $1,000 \mu \mathrm{g} / \mathrm{l}$ total VOC isoconcentration contour, with an objective to reduce concentrations and control migration of VOCs within the $1,000 \mu \mathrm{g} / \mathrm{l}$ contour.

This IAPP establishes a final goal for the ballast area. The ballast area will not require additional remedial action. Since this is an interim action for the vadose zone and the groundwater hot spot., quantitative remediation goals are not specified The final remedial goals for the vadose zone and groundwater will be consistent with applicable or relevant and appropriate requirements (ARARs) and will mitigate any reasonable risk to human health and the environment. 
Table 5. Ballast Area RGs

\begin{tabular}{|c|c|c|c|c|c|c|c|c|c|c|}
\hline \multirow[t]{2}{*}{$\mathrm{COC}$} & \multirow[t]{2}{*}{ RME } & \multicolumn{3}{|c|}{$\begin{array}{l}\text { Human Health RGs by risk } \\
\text { range (without produce)" }\end{array}$} & \multicolumn{3}{|c|}{ Industrial RGs by risk range } & \multirow{2}{*}{$\begin{array}{c}\begin{array}{c}\text { Ecological } \\
\text { RGs }\end{array} \\
H Q \geq 1\end{array}$} & \multirow[t]{2}{*}{ ARAR } & \multirow[t]{2}{*}{$\begin{array}{c}\text { Recommended } \\
\text { RG }^{*}(\mu \mathrm{g} / \mathrm{kg})\end{array}$} \\
\hline & & $1 \times 10^{-6}$ & $1 \times 10^{-5}$ & $1 \times 10^{-4}$ & $1 \times 10^{-6}$ & $1 \times 10^{-5}$ & $1 \times 10^{-4}$ & & & \\
\hline \multicolumn{11}{|l|}{ PCB } \\
\hline $\begin{array}{l}\text { Aroclor- } \\
1248\end{array}$ & 2110 & 110 & 1,110 & 11,100 & 320 & 3,200 & 32,000 & - & & $<1000$ \\
\hline \multicolumn{11}{|l|}{ Pesticides } \\
\hline Heptachlor & 310 & 180 & 1,800 & 18,000 & $3 x$ & 4,900 & 49,000 & - & - & 490 \\
\hline Dieldrin & 200 & 47 & 470 & 4,700 & 110 & 1,100 & 11,000 & & - & 50 \\
\hline Endrin & 400 & - & - & - & - & -- & - & & - & 60 \\
\hline DDD & 100 & - & - & - & - & - & - & & - & 10 \\
\hline DDE & 100 & - & - & - & - & - & - & & - & 20 \\
\hline DDT & 22000 & - & - & - & - & - & - & & - & 60 \\
\hline
\end{tabular}

(Constituent RG units in $\mu \mathrm{g} / \mathrm{kg}$. Shaded boxes represent recommended RGs.)

Notes:

The recommended RGs are protective of human health and the environment and are based upon the long-term strategy for the CMP Pits area. Although the CMP Pits area is located outside of the Industrial Use Zone (defined by Figure 3-3 of the FFA Implementation Plan), it is anticipated that the CMP Pits area will be a limited use area with restrictions similar to an industrial use zone. Unrestricted residential land use of the CMP Pits area would result in an unnecessary increase in human health risk due to excavation in the vadose zone, and disturbance of the existing protective cap and drainage systems previously placed over the disposal pits. Restricting land use and institutional controls are necessary at this unit to provide continued protection to human health and the environment from exposure to contaminants and to prevent destruction of the previous remedial action.

Since the ballast area will be a final action, the recommended RGs are considered final RGs. The recommended RG for heptachlor is therefore based upon the industrial scenario and is protective of the industrial worker ( $1 \times 10^{-6}$ risk). The $\mathrm{RG}$ for Aroclor-1248 is an action level based upon promulgated clean up standards (40CFR Par 761 Disposal of PCB; Final Rule) and is also protective of the industrial worker. The RGs for dieldrin, endrin, p,p'-DDD, p.p'-DDE, and p,p'-DDT are based upon ecological risks.

Footnotes:

RG is for a child resident

b. Potential RG scenarios for Aroclor-1248:

No further action: $<=1000 \mu \mathrm{g} / \mathrm{kg}$

High Occupancy area ( 335 hours/year) - covered with a cap meeting requirements specified in the regulations: $>1000 \mu \mathrm{g} / \mathrm{kg}$ and $<=$ $10000 \mu \mathrm{g} / \mathrm{kg}$

Low Occupancy area $-<=25000 \mu g / \mathrm{kg}$

c. The recommended RG for Aroclor-1248 is consistent with the action level requirements for disposal of PCB. Recommended RGs for pesticides are based upon the human health risk to the future industrial worker $\left(1 \times 10^{-6}\right)$ or upon the ecological risk.

-. - Not a Human Health or Ecological COC or no ARAR available 


\section{Section V.A Description of Nine Evaluation Criteria}

An alternative analysis was conducted to support the development of a Rev. 1.2 CMS/FS for the CMP Pits (WSRC, 1998). The alternative analysis is used as a basis for selecting appropriate interim action alternatives for CMP Pits contaminated soil and groundwater.

The alternative analysis identified five alternatives for soils (ballast area and vadose zone) and three alternatives for groundwater. Each of the remedial alternatives were evaluated using the nine criteria established by the National Oil and Hazardous Substances Pollution Contingency Plan (NCP). The criteria were derived from the statutory requirements of CERCLA Section 121. The NCP [40 CFR § 300.430 (e) (9)] sets forth nine evaluation criteria that provide the basis for evaluating alternatives and selecting a remedy.

The first seven criteria are used to evaluate all the alternatives based on human health and environmental protection, cost, and feasibility issues. The preferred alternative is further evaluated using the final two criteria: state acceptance and community acceptance. Brief descriptions of all nine criteria are given below.

Overall Protection of Human Health and the Environment - Remedial alternatives are assessed to determine the degree to which each alternative eliminates, reduces, or controls threats to human health and the environment through treatment, engineering methods, or institutional controls.

Compliance with Applicable or Relevant and Appropriate Requirements - ARARs are federal and state environmental regulations that establish standards that remedial actions must meet unless waived consistent with the NCP. There are three types of ARARs: (1) chemical-specific, (2) location-specific, and (3) action-specific.

Chemical-specific ARARs are usually health- or riskbased levels or methodologies that, when applied to unit-specific conditions, result in the establishment of numerical values. Often these numerical values are promulgated in federal or state regulations.

Location-specific ARARs are restrictions placed on the concentration of hazardous substances or the conduct of activities solely because they are in specific locations. Some examples of specific locations include floodplains, wetlands, historic places, and sensitive ecosystems or habitats.
Action-specific ARARs are usually technology- or remedial activity-based requirements or limitations on actions taken with respect to hazardous substances or unit-specific conditions. These requirements are triggered by the particular remedial activities selected to accomplish a remedy.

In addition to ARARs, compliance with other criteria, guidance, and proposed standards that are not legally binding, but may provide useful information or recommended procedures, should be reviewed as to-beconsidered when setting remedial objectives.

Long-Term Effectiveness and Permanence - Remedial alternatives are assessed based on their ability to maintain reliable protection of human health and the environment after implementation.

Reduction of Toxicity, Mobility, or Volume Through Treatment - Remedial alternatives are assessed based on the degree to which they employ treatment that reduces toxicity (harmful nature of contaminants), mobility (ability of contaminants to move through the environment), or volume of contaminants associated with the unit.

Short-Term Effectiveness - Remedial alternatives are assessed considering factors relevant to implementation of the remedial action, including risks to the community during implementation, impacts on workers, potential environmental impacts (e.g., air emissions), and the time until protection is achieved.

Implementability - Remedial alternatives are assessed by considering the difficulty of implementing the alternative, including technical feasibility, constructability, reliability of technology, ease of undertaking additional remedial actions (if required), monitoring considerations, administrative feasibility (regulatory requirements), and availability of services and materials.

Cost - Evaluation of remedial alternatives must include capital and operational and maintenance costs. Present value costs are estimated within $+50 /-30$ percent, per US EPA guidance. Cost estimates given with each alternative are prepared from information available at the time of the estimate. Final costs of the project will depend on actual labor and material costs, actual site conditions, productivity, competitive market conditions, final project scope, final project schedule, and other variable factors. Therefore, the final project costs may vary from the estimates presented herein.

State Acceptance - The State is requested to comment on the Remedial Investigation Report, the Baseline Risk Assessment, and the Interim Action Proposed 
Plan. The State's concurrence or opposition to the preferred alternative is considered.

Community Acceptance - Community acceptance of the preferred alternative is assessed by giving the public an opportunity to comment on the remedy selection process. A public comment period is held and public comments concerning the proposed remedy are incorporated in the Responsiveness Summary of the IROD.

\section{Section V.B Summary of Alternatives}

This section summarizes the alternatives for the ballast area, vadose zone and groundwater hot spot. A comparison of the alternatives against the nine CERCLA criteria is included in Tables 6,7 , and 8. The rationale for the selection of the preferred alternative is presented in Section V.C. (The "BA" associated with the alternatives refers to ballast area alternatives. The "VZ" associated with the alternatives refers to the vadose zone alternatives and the "GWHS" refers to the groundwater hot spot alternatives.)

\section{Summary of Alternatives for the Ballast Area}

\section{Alternative BA-1: No Action \\ The "no action" option is required by the NCP to serve as the base line for comparison with other remediation methods. Under this alternative, no remedial efforts would be conducted to remove, treat, or otherwise lessen the toxicity, mobility, or affected volume of contaminated media. Institutional controls similar to those that already exist would not continue under this scenario.}

The No Action Alternative would not be protective of human health because of risk of direct contact by an industrial worker or hypothetical future resident. The No Action Alternative would not be protective of the environment because of risk of ingestion of contaminants by terrestrial ecological receptors. Concentration-based remediation goals in surface soil would not be met.

\section{Alternative BA-2: Install RCRA Cap Over the Ballast Area}

Alternative BA-2 entails installation of a RCRA cap over the ballast area to eliminate direct contact of PCB and pesticide contamination. A RCRA cap would be required to be protective of the pesticide contamination that is listed hazardous waste.
Alternative BA-2 would eliminate potential human or environmental exposure in the primary transport/exposure pathways (direct contact and biouptake in the food web). Alternative BA-2 would not be protective of the future worker involved in the remediation of the vadose zone or the groundwater hot spot. Alternative BA-2 would effectively reduce mobility by minimizing bio-uptake and stormwater runoff. Concentration-based remediation goals in surface soil would not be met.

Alternative BA-3: Remove the Ballast Area Soils, Dispose Off Site, and Backfill to Grade

Alternative BA- 3 entails excavation of contaminated soil within the ballast area, off site shipment and disposal, and backfilling the excavated area to grade. Land use controls would be a component of Alternative BA-3 to address residual contamination .

Alternative BA-3 would be protective of human health and the environment. Contaminated soil exceeding RGs present in the ballast area would be permanently removed from the unit eliminating human or ecological exposure, bio-uptake and stormwater runoff. Concentration-based remediation goals in surface soil would be met.

In 1996, clean soil was placed over the ballast area to prevent soil erosion and movement of contaminated material. Alternative BA-3 would perform sampling to confirm that the top 6" is still clean uncontaminated soil. After confirmation, the clean soil will be removed and segregated to use later as replacement backfill and minimize the amount of soil sent off SRS for disposal. Contaminated soils removed will be disposed of at a commercial RCRA permitted facility, in compliance with the CERCLA Offsite Rule. Because the soils are considered a RCRA hazardous waste and subject to the RCRA Land Disposal Restrictions they will require treatment prior to disposal consistent with the regulations. The soils also may contain $\mathrm{PCBs}$ that are regulated under TSCA, and the use of a RCRA hazardous waste landfill will comply with the new requirements for disposal of PCB remediation waste under 761.61 .

Under this alternative, the decontamination fluids are expected to be below health based values and will be delisted (i.e. shown to be non-hazardous wastes) and thus will no longer be subject to RCRA Subtitle $\mathrm{C}$ hazardous waste regulations. The decontamination fluids found to be below the values for pesticides 
listed in the IDW management plan will be disposed of on unit.

\section{Summary of Alternatives for the Vadose Zone}

\begin{abstract}
Alternative VZ-1: No Action
The "no action" option is required by the NCP to serve as the base line for comparison with other remediation methods. Under this alternative, no remedial efforts would be conducted to remove, treat, or otherwise lessen the toxicity, mobility, or affected volume of contaminated media. Institutional controls similar to those that already exist (cable barrier, groundwater monitoring) would not continue under this No Action scenario.
\end{abstract}

The No Action Alternative would not include maintenance of the existing synthetic membrane cap over the Pits Area. The No Action Alternative would not be protective of human health because of risk due to groundwater ingestion by a hypothetical future resident. Vertical migration of contaminants from the vadose zone to groundwater and further transport within the aquifers would continue unabated.

Alternative VZ-2: Conduct Soil Vapor Extraction (SVE) in Subsurface Soils and Install Asphalt Cover to Provide Infiltration Control

Alternative VZ-2 entails installation of an SVE system in the pit area to remove volatilized contaminants from the soil. An asphalt cover would be placed over the area to minimize infiltration and prevent leaching. Potential system modifications would consist of active and passive enhancements to the SVE system. Active enhancements could include modifications to the SVE configuration. Passive systems such as a barometric pumping system could also be installed. Based upon soil gas surveys and engineering calculations no offgas treatment would be required to maintain VOC emissions within air quality permit limits.

Alternative VZ-2 provides moderate protection of human health and the environment. Upon completion of the characterization to determine the extent of the plume, an appropriate final strategy for the vadose zone and groundwater hot spot will be developed and the final Record of Decision will be submitted for review and approval consistent with the enclosed schedule (Figure 10).

Under this alternative, the decontamination fluids are expected to be below health based values and will be delisted (i.e. shown to be non-hazardous wastes) and thus will no longer be subject to RCRA Subtitle $\mathrm{C}$ hazardous waste regulations. The decontamination fluids found to be below the values for VOCs listed in the IDW management plan will be disposed of on unit.

\section{Summary of Alternatives for the Groundwater Hot Spot}

\section{Alternative GWHS-1: No Action}

The "no action" option is required by the NCP to serve as the base line for comparison with other remediation methods. Under this alternative, no remedial efforts would be conducted to remove, treat, or otherwise lessen the toxicity, mobility, or affected volume of contaminated groundwater. Groundwater concentrations would continue to exceed MCLs.

Alternative GWHS-2: Conduct Air Sparging in Groundwater Hot Spot with SVE

Alternative GWHS-2 entails installation of AS/SVE points in the area of the contamination plume with VOC concentrations greater than $1,000 \mu \mathrm{g} / 1$. The AS/SVE system will volatilize contaminants in the groundwater and remove them from the soil vapor pháse just above the water table surface.

The groundwater remediation would include two AS/SVE systems identified as Field A and Field B. Fields A and B encompass areas approximately 300 to 500 feet wide by 350 to 450 feet long where the aquifer thickness is 25 feet. Figure 8 illustrates the sparge and extraction points with respect to the VOC contours.

AS/SVE was selected to treat the hot spot because the water table aquifer in the area is thought to be relatively low in hydraulic permeability and therefore extractive techniques are likely to be impracticable. However, the permeability of the formation for air is thought to be sufficiently high to make injection of air practicable. The air sparging within the water table aquifer reduces VOC concentrations by promoting the volatilization of the VOCs from the water. SVE is required to remove the vapors from the vadose zone prior to condensation of the vapors.

The air sparging points are expected to have an effective radius of approximately 15 feet. The local spacing of air sparging points and SVE points on Figure 8 is consistent with the anticipated effective area. The overall arrangement of SVE/AS fields is consistent with the demonstrated migration paths of 
the hot spot VOCs from the source area to the distal portions of the groundwater plume, and the highest known concentrations of VOCs.

SRS believes that the large number of injection and extraction points will have a rapid and significant impact on the concentrations of VOCs within the water table in the vicinity of the pits and downgradient. In addition, SRS believes that the number and position of the points is appropriate for an interim action, considering that some points may be determined to be not be as effective as others, and additional points may be added as needed based upon system operating performance. The AS and SVE points will be installed using direct push technology.

No offgas treatment would be required to maintain VOC emissions within air quality permit limits. Figure 9 illustrates the conceptual design for the CMP Pits groundwater hot spot remediation. Active enhancements to the AS system may include modifications to the injection system configuration or injection of nutrients and methane. Appropriate and necessary underground injection permit approvals will be obtained from SCDHEC prior to injection of nutrients, methane, etc. in subsurface.

Alternative GWHS-2 would provide moderate protection of human health and the environment. The AS/SVE system would be operated until the point of diminishing returns is reached, as agreed to by US DOE, US EPA, and SCDHEC. MCLs for individual constituents (e.g., PCE) may continue to be exceeded in the groundwater at the end of the interim action.

Costs associated with Alternative GWHS-2 include labor and materials to install the SVE and AS points and blower systems. Included in the costs is operation and maintenance for a period of approximately 5 years and administrative controls (i.e., maintenance of existing CMP Pits access controls, groundwater sampling, site maintenance activities, etc.) costs.

Under this alternative, the decontamination fluids are expected to be below health based values and will be delisted (i.e. shown to be non-hazardous wastes) and thus will no longer be subject to RCRA Subtitle $\mathrm{C}$ hazardous waste regulations. The decontamination fluids found to be below the values for VOCs listed in the IDW management plan will be disposed of on unit.
Alternative GWHS-3: Remove Groundwater in Hot Spots and Treat using Air Stripping/Carbon Adsorption

Alternative GWHS-3 entails installation of a groundwater extraction system designed to treat the water table zone hot spots. Aquifer pumping tests would be performed during the remedial design phase to select well diameter and spacing, pumping rates, capture zones, and groundwater quality.

Conceptual layout of the system includes approximately six 4-in. diameter wells spaced approximately 150 feet apart within the plume hot spots in the Pits Area. The initial extraction rate is estimated at approximately 16,500 gpd per well for the first 100 days of pumping until a drawdown of approximately 5.8 feet is achieved. The steady-state rate of extraction is estimated at $8,000 \mathrm{gpd}$ per well, or a total of $48,000 \mathrm{gpd}$ from the well array. The number of wells pumped may be reduced as the groundwater extraction system is operated, as the zone of contamination is reduced.

Extracted groundwater would be treated on site using ex situ air stripping, followed by activated carbon adsorption as a polishing step. The conceptual process design involves the use of two air stripping towers, each about 2 feet in diameter and 19 feet tall, filled with packing material. Each tower would have an operating capacity of $90 \mathrm{gpm}$ and $1,550 \mathrm{cfm}$ air flow. Approximately two carbon adsorption units would be used in conjunction with the towers. Depending on the groundwater chemistry, a pretreatment step, such as iron precipitation, may be required to prevent fouling. Once treated, the residual groundwater would be discharged directly to Pen Branch. Residual solids and spent carbon would be disposed of off site at a permitted commercial hazardous waste disposal facility.

Alternative GWHS-3 would be moderately protective of human health and the environment. Groundwater contamination within the water table zone would be reduced and the extracted contaminants would be permanently removed. Groundwater extraction is a well-established and proven technology for removal of VOCs at other hazardous waste sites. 
Fyure 8. CMP Pits ASSVE Well Locations and VOC Contours (19/)

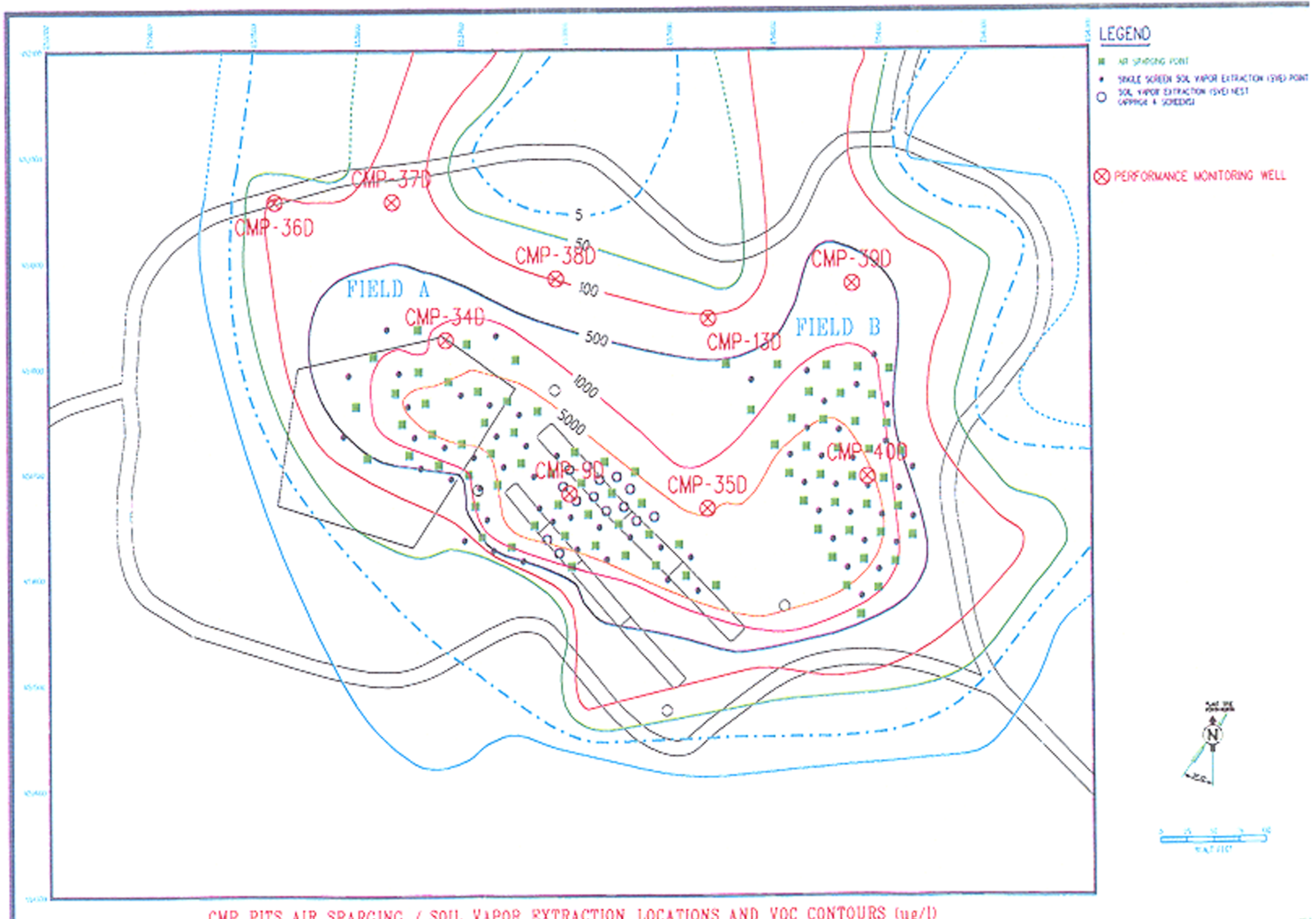

CMP PITS AIR SPARGING / SOLL VAPOR BXTRACTION LOCATIONS AND VOC CONTOURS (ug/l) 


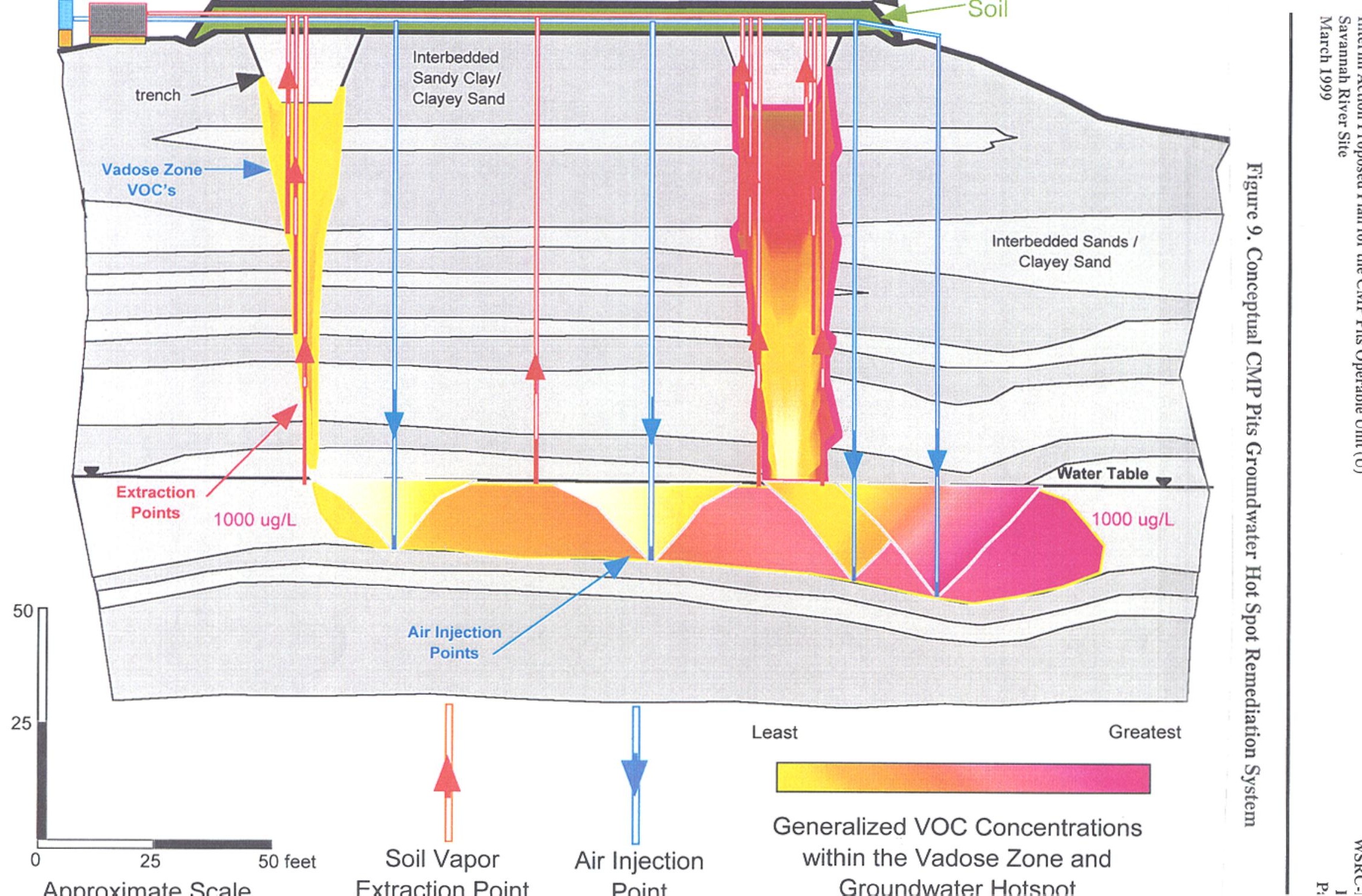


Table 6 Summary of the Ballast Area alternative screening

\begin{tabular}{|c|c|c|c|}
\hline \multicolumn{4}{|c|}{$\begin{array}{l}\text { Corrective Measure/Remedial Action Alternatives for the Ballast Area Surface Soils } \\
\text { (includes Pits Area Perimeter Surface Soils) }\end{array}$} \\
\hline Criterion & $\begin{array}{l}\text { Alternative BA-1 } \\
\text { No Action }\end{array}$ & $\begin{array}{l}\text { Alternative BA-2 } \\
\text { Install RCRA Cap }\end{array}$ & $\begin{array}{l}\text { Alternative BA-3 } \\
\text { Excavation/Disposal }\end{array}$ \\
\hline \multicolumn{4}{|l|}{ Overall Protectiveness } \\
\hline Human Health & $\begin{array}{l}\text { Not protective of future } \\
\text { industrial worker }\end{array}$ & Protective & Protective \\
\hline Environment & Not protective & Protective & Protective \\
\hline Control of Source Release & $\begin{array}{l}\text { No control; bio-uptake to } \\
\text { food web; leaching to } \\
\text { groundwater would continue }\end{array}$ & $\begin{array}{l}\text { Moderate control; bio-uptake would be } \\
\text { reduced by greater root zone }\end{array}$ & $\begin{array}{l}\text { High control; bio-uptake eliminated by removing } \\
\text { source }\end{array}$ \\
\hline \multicolumn{4}{|c|}{ Effectiveness in Meeting Remedial Action Objectives } \\
\hline $\begin{array}{l}\text { Prevent Direct Soil Contact } \\
\text { of Future Industrial } \\
\text { Workers to pesticides and } \\
\text { PCBs in soil }\end{array}$ & Not effective & $\begin{array}{l}\text { Effective, dependent on maintenance of } \\
\text { cap }\end{array}$ & Effective, contaminated soil would be removed \\
\hline $\begin{array}{l}\text { Prevent Exposure of } \\
\text { Terrestrial Predators to } \\
\text { Soils and Through Bio- } \\
\text { uptake Above an } \\
\text { Ecological Hazard } \\
\text { Quotient of Unity } \\
\end{array}$ & Not effective & $\begin{array}{l}\text { Effective, dependent on maintenance of } \\
\text { cap }\end{array}$ & Effective, contaminated soil would be removed \\
\hline $\begin{array}{l}\text { Effectiveness in Meeting } \\
\text { Remediation Goals }\end{array}$ & Goals not met & Goals not met & Goals met \\
\hline \multicolumn{4}{|c|}{ Compliance With ARARs } \\
\hline Chemical-specific & $\begin{array}{l}\text { 40CFR } 761 \text { - TSCA, } \\
\text { Disposal of PCBs High } \\
\text { Occupancy would not be } \\
\text { met }\end{array}$ & $\begin{array}{l}\text { 40CFR } 761 \text { - TSCA, Disposal of } \\
\text { PCBs High Occupancy would not be } \\
\text { met }\end{array}$ & $\begin{array}{l}\text { Meets ARARs, The decontamination fluids will be } \\
\text { delisted. The RCRA Subtitle C requirements will } \\
\text { no longer be ARARs for these secondary wastes } \\
\text { that will be disposed of on-unit. }\end{array}$ \\
\hline Location-specific & Not applicable & Not applicable & Not applicable \\
\hline Action-specific & No action-specific ARARs & $\begin{array}{l}\text { SC Fugitive Particulate regulations } \\
\text { apply to dust emissions; NESHAPs; } \\
\text { RCRA requirements under 40CFR } 264 \\
\text { for capping and } 40 \text { CFR } 266 \text { for listed } \\
\text { waste and contaminated PPE }\end{array}$ & $\begin{array}{l}\text { TSCA regulations apply to treatment of PCB- } \\
\text { contaminated soil; FIFRA regulations apply to } \\
\text { treatment of pesticide-contaminated soil; RCRA } \\
\text { regulations for hazardous waste generation, } \\
\text { characterization, transportation, treatment. } \\
\text { storage, and disposal apply to the off-site disposal } \\
\text { of wastes (including land disposal restrictions) }\end{array}$ \\
\hline \multicolumn{4}{|c|}{ Long-Term Effectiveness and Permanence } \\
\hline Magnitude of residual risks & $\begin{array}{l}\text { Ballast Area would be a } \\
\text { continued source of risk to } \\
\text { the environment; residual } \\
\text { risks to future industrial } \\
\text { worker }\end{array}$ & $\begin{array}{l}\text { Residual risks reduced over current } \\
\text { conditions as long as cap remains intact }\end{array}$ & Residual risks eliminated \\
\hline Adequacy of controls & $\begin{array}{l}\text { Not adequately protective of } \\
\text { future worker or } \\
\text { environment }\end{array}$ & $\begin{array}{l}\text { Adequate as long as institutional } \\
\text { controls and cap maintenance are } \\
\text { continued }\end{array}$ & $\begin{array}{l}\text { Adequate; as long as land use controls are } \\
\text { maintained }\end{array}$ \\
\hline Permanence & Not permanent & $\begin{array}{l}\text { Permanent cap as long as controls are } \\
\text { maintained: leaves contaminated soil } \\
\text { on site }\end{array}$ & Permanent \\
\hline
\end{tabular}


Table 6 Summary of the Ballast Area alternative screening (Continued) Corrective Measure/Remedial Action Alternatives for the Ballast Area Surface Soils (includes Pits Area Perimeter Surface Soils)

\begin{tabular}{|c|c|c|c|}
\hline Criterion & $\begin{array}{l}\text { Alternative BA-1 } \\
\text { No Action }\end{array}$ & $\begin{array}{l}\text { Alternative BA-2 } \\
\text { Install RCRA Cap }\end{array}$ & $\begin{array}{c}\text { Alternative BA-3 } \\
\text { Excavation/Disposal }\end{array}$ \\
\hline \multicolumn{4}{|c|}{ Reduction of Toxicity, Mobility, or Volume } \\
\hline $\begin{array}{l}\text { Treatment process used and } \\
\text { materials treated } \\
\end{array}$ & No treatment & No treatment & $\begin{array}{l}\text { PCB and Pesticide contaminated soil will be } \\
\text { treated (stabilized/incinerated) as required }\end{array}$ \\
\hline $\begin{array}{l}\text { Degree of expected } \\
\text { reduction in toxicity, } \\
\text { mobility, or volume }\end{array}$ & Not Applicable & $\begin{array}{l}\text { Capping would reduce contaminant } \\
\text { mobility in soil as long as cap integrity } \\
\text { is maintained }\end{array}$ & Excavation would remove soil contamination \\
\hline $\begin{array}{l}\text { Amount of hazardous } \\
\text { materials destroyed or } \\
\text { treated }\end{array}$ & Not Applicable & $\begin{array}{l}\text { None; would minimize bio-uptake in } \\
\text { Ballast Area }\end{array}$ & $\begin{array}{l}\text { Would treat } 1300 \mathrm{yd}^{3} \text { of Ballast Area soil and } \\
\text { destroy } 8.8 \mathrm{~kg} \text { of contaminants }\end{array}$ \\
\hline $\begin{array}{l}\text { Degree to which treatment } \\
\text { is irreversible }\end{array}$ & Not Applicable & $\begin{array}{l}\text { No treatment; cap could be removed in } \\
\text { future to reverse this action }\end{array}$ & $\begin{array}{l}\text { Contaminant removal and treatment are } \\
\text { irreversible }\end{array}$ \\
\hline $\begin{array}{l}\text { Types and quantities of } \\
\text { residuals remaining after } \\
\text { treatment }\end{array}$ & Not Applicable & $\begin{array}{l}\text { Sampling derived waste (minor } \\
\text { volumes) }\end{array}$ & Sampling derived waste (minor volumes) \\
\hline \multicolumn{4}{|l|}{ Short-term effectiveness } \\
\hline Risks to workers & $\begin{array}{l}\text { Exceeds human health } \\
\text { (future industrial worker) } \\
\text { RGs }\end{array}$ & $\begin{array}{l}\text { Moderate; potential risk due to } \\
\text { inhalation or direct contact during cap } \\
\text { placement; OSHA and applicable work } \\
\text { safety and health regulations will be } \\
\text { followed }\end{array}$ & $\begin{array}{l}\text { Moderate; potential risk due to inhalation or } \\
\text { direct contact during soil excavation; } \\
\text { disturbance and handling of contaminated soil; } \\
\text { OSHA and applicable work safety and health } \\
\text { regulations will be followed }\end{array}$ \\
\hline Risk to community & None & Negligible; no public areas near unit & Minimal; off-site transport of contaminated soil \\
\hline Risk to environment & Exceeds environment RGs & $\begin{array}{l}\text { Negligible; potential risk due to soil } \\
\text { erosion during cap placement }\end{array}$ & $\begin{array}{l}\text { Moderate; potential risk due to soil erosion } \\
\text { during Ballast Area excavation; spills during } \\
\text { off-site transport and disposal of soils }\end{array}$ \\
\hline $\begin{array}{l}\text { Time to achieve remedial } \\
\text { action objectives }\end{array}$ & 0 months & 3 months & 4 months \\
\hline \multicolumn{4}{|l|}{ Implementabilty } \\
\hline $\begin{array}{l}\text { Availability of materials, } \\
\text { equipment, contractors }\end{array}$ & Not applicable & Readily available & Readily available \\
\hline $\begin{array}{l}\text { Ability to construct and } \\
\text { operate the technology }\end{array}$ & Not applicable & Difficult to construct & $\begin{array}{l}\text { Well demonstrated and commonly used } \\
\text { technologies }\end{array}$ \\
\hline $\begin{array}{l}\text { Ability to obtain } \\
\text { permits/approvals from } \\
\text { other agencies }\end{array}$ & $\begin{array}{l}\text { Readily implementable; } \\
\text { 5-year remedy reviews } \\
\text { required }\end{array}$ & $\begin{array}{l}\text { Readily implementable; } \\
\text { 5-year remedy reviews required }\end{array}$ & $\begin{array}{l}\text { Implementable; off-site disposal facility } \\
\text { already permitted }\end{array}$ \\
\hline $\begin{array}{l}\text { Ability to monitor } \\
\text { effectiveness of remedy }\end{array}$ & Not applicable & $\begin{array}{l}\text { Readily implementable; surface water } \\
\text { and biota monitoring required }\end{array}$ & $\begin{array}{l}\text { Implementable; soil screening required during } \\
\text { excavation }\end{array}$ \\
\hline $\begin{array}{l}\text { Ease of undertaking } \\
\text { additional actions (if } \\
\text { required) }\end{array}$ & Easy & $\begin{array}{l}\text { Not compatible; capping would } \\
\text { preclude future soil removal or } \\
\text { treatment (AS/SVE) }\end{array}$ & Compatible \\
\hline Time to implement & 0 months & 3 months & 4 months construct \\
\hline \multicolumn{4}{|l|}{ Cost } \\
\hline Present Worth Capital Cost & $\$ 0$ & $\$ 3,212,000$ & $\$ 2,866,000$ \\
\hline Present Worth O\&M Cost & $\$ 50,000$ & $\$ 261,000$ & $\$ 0$ \\
\hline Total Present Worth Cost & $\$ 50,000$ & $\$ 3,473,000$ & $\$ 2,866,000$ \\
\hline
\end{tabular}


Table 7 Summary of the Vadose Zone alternative screening

\begin{tabular}{|c|c|c|}
\hline & \multicolumn{2}{|c|}{ Corrective Measure/Remedial Action Alternatives for the Pits Area Subsurface Soils } \\
\hline Criterion & $\begin{array}{l}\text { Alternative VZ-1 } \\
\text { No Action }\end{array}$ & $\begin{array}{c}\text { Alternative VZ-2 } \\
\text { In Situ Soil Vapor Extraction and Asphalt Cover }\end{array}$ \\
\hline \multicolumn{3}{|l|}{ Overall Protectiveness } \\
\hline Human Health & Not protective of leaching to groundwater & Protective \\
\hline Environment & Not protective of leaching to groundwater & Protective \\
\hline \multicolumn{3}{|c|}{ Effectiveness in Meeting Remedial Action Objectives } \\
\hline $\begin{array}{l}\text { Prevent Leaching to } \\
\text { groundwater }\end{array}$ & Not effective & Effective; contaminants in soils would be removed \\
\hline $\begin{array}{l}\text { Effectiveness in Meeting } \\
\text { Remediation Goals }\end{array}$ & Goals not met & At end of Interim Action VOCs in soil reduced 100-fold \\
\hline \multicolumn{3}{|c|}{ Compliance With ARARs } \\
\hline Chemical-specific & None & $\begin{array}{l}\text { SC Air Pollution Regulations and Standards, applied to } \\
\text { Construction Permit, Visible Emissions, and Toxic Air Pollutan } \\
\text { Requirements }\end{array}$ \\
\hline Location-specific & None & $\begin{array}{l}\text { Measures required to prevent impact to neighboring wetlands } \\
\text { (Pen Branch) }\end{array}$ \\
\hline Action-specific & None & $\begin{array}{l}\text { RCRA Land Treatment and Hazardous Waste Generator } \\
\text { regulations apply to in situ SVE treatment; SC Toxic Air } \\
\text { Pollutant regulations apply to air emissions; SC Fugitive } \\
\text { Particulate regulations apply to dust emissions; SC Construction } \\
\text { and Operating permits apply to well construction; LDRs for all } \\
\text { PPE and treatment residues }\end{array}$ \\
\hline \multicolumn{3}{|c|}{ Long-Term Effectiveness and Permanence } \\
\hline Magnitude of residual risks & $\begin{array}{l}\text { CMP Pits waste unit would be a continued source of } \\
\text { contamination to the environment; residual risks to } \\
\text { future resident as result of groundwater ingestion }\end{array}$ & $\begin{array}{l}\text { Residual risks reduced over current conditions; soil } \\
\text { contamination reduced } 100 \text {-fold. }\end{array}$ \\
\hline Adequacy of controls & $\begin{array}{l}\text { Not adequately protective of future resident or } \\
\text { environment }\end{array}$ & Adequate as long as institutional controls are continued \\
\hline Permanence & Not permanent & Not permanent \\
\hline \multicolumn{3}{|c|}{ Reduction of Toxicity, Mobility, or Volume } \\
\hline $\begin{array}{l}\text { Treatment process used and } \\
\text { materials treated }\end{array}$ & None & $\begin{array}{l}\text { In situ SVE of Pits Area Soils; system enhancements such as } \\
\text { barometric pumping and methane injection }\end{array}$ \\
\hline $\begin{array}{l}\text { Degree of expected } \\
\text { reduction in toxicity, } \\
\text { mobility, or volume }\end{array}$ & None & $\begin{array}{l}\text { SVE would reduce volume (mass) of contaminants in Pits Area } \\
\text { soil, significantly reduce mobility to groundwater and reduce } \\
\text { discharge to air through treatment, asphalt cover will reduce } \\
\text { mobility }\end{array}$ \\
\hline $\begin{array}{l}\text { Amount of hazardous } \\
\text { materials destroyed or } \\
\text { treated }\end{array}$ & None & $\begin{array}{l}\text { Would treat } 9,900 \mathrm{yd}^{3} \text { of Pits Area soil and reduce volume } \\
\text { (mass) by } 14,240 \mathrm{~kg}\end{array}$ \\
\hline $\begin{array}{l}\text { Degree to which treatment } \\
\text { is irreversible }\end{array}$ & No treatment & Contaminant removal and treatment are irreversible \\
\hline $\begin{array}{l}\text { Types and quantities of } \\
\text { residuals remaining after } \\
\text { treatment }\end{array}$ & None & $\begin{array}{l}\text { SVE air emissions ( } 300 \mathrm{scfm}) \text {; condensate ( } 1 \mathrm{gpd}) \text {; soil cuttings } \\
\left(30 \mathrm{yd}^{3}\right)\end{array}$ \\
\hline
\end{tabular}


Table 7 Summary of the Vadose Zone alternative screening (Continued)

\begin{tabular}{|c|c|c|}
\hline & \multicolumn{2}{|c|}{ Corrective Measure/Remedial Action Alternatives for the Pits Area Subsurface Soils } \\
\hline Criterion & $\begin{array}{l}\text { Alternative VZ-1 } \\
\text { No Action }\end{array}$ & $\begin{array}{c}\text { Alternative VZ-2 } \\
\text { In Situ Soil Vapor Extraction and Asphalt Cover }\end{array}$ \\
\hline \multicolumn{3}{|l|}{ Short-term effectiveness } \\
\hline Risks to workers & None & $\begin{array}{l}\text { Minimal; potential risk due to inhalation or direct contact } \\
\text { during extraction point installation; potential vapor inhalation } \\
\text { during SVE system operation; OSHA and applicable work } \\
\text { safety and health regulations will be followed }\end{array}$ \\
\hline Risk to community & None & Negligible; no public areas near unit \\
\hline Risk to environment & None & $\begin{array}{l}\text { Minimal; potential risk during direct push installation of AS and } \\
\text { SVE points; permitted air emissions }\end{array}$ \\
\hline $\begin{array}{l}\text { Time to achieve remedial } \\
\text { action objectives }\end{array}$ & 0 months & 72 months \\
\hline \multicolumn{3}{|l|}{ Implementabilty } \\
\hline $\begin{array}{l}\text { Availability of materials, } \\
\text { equipment, contractors }\end{array}$ & Not applicable & Readily available \\
\hline $\begin{array}{l}\text { Ability to construct and } \\
\text { operate the technology }\end{array}$ & Not applicable & Straightforward, commonly used technologies \\
\hline $\begin{array}{l}\text { Ability to obtain } \\
\text { permits/approvals from } \\
\text { other agencies }\end{array}$ & $\begin{array}{l}\text { Readily implementable; } \\
5 \text {-year remedy reviews required }\end{array}$ & $\begin{array}{l}\text { Implementable; air emissions permit required; 5-year remedy } \\
\text { reviews required }\end{array}$ \\
\hline $\begin{array}{l}\text { Ability to monitor } \\
\text { effectiveness of remedy }\end{array}$ & Not applicable & $\begin{array}{l}\text { Readily implementable; groundwater monitoring required; air } \\
\text { quality monitoring of SVE emissions required }\end{array}$ \\
\hline $\begin{array}{l}\text { Ease of undertaking } \\
\text { additional actions (if } \\
\text { required) }\end{array}$ & Not incompatible & $\begin{array}{l}\text { Not incompatible; SVE wells would penetrate existing cap } \\
\text { requiring placement of an asphalt cover over the site }\end{array}$ \\
\hline Time to implement & 0 months & 12 months constructitest \\
\hline \multicolumn{3}{|l|}{ Cost } \\
\hline Present Worth Capital Cost & $\$ 0$ & $\$ 674,000$ \\
\hline Present Worth O\&M Cost & $\$ 50,000$ & $\$ 469,000$ \\
\hline Total Present Worth Cost & $\$ 50,000$ & $\$ 1,143,000$ \\
\hline
\end{tabular}


Table 8 Summary of the Groundwater Hot Spot alternative screening

\begin{tabular}{|c|c|c|c|}
\hline & \multicolumn{3}{|c|}{ Corrective Measure/Remedial Action Alternatives for the Pits Area Groundwater Hot Spot } \\
\hline Criterion & $\begin{array}{c}\text { Alternative GWHS-1 } \\
\text { No Action }\end{array}$ & $\begin{array}{l}\text { Alternative GWHS-2 } \\
\text { Air Sparging with SVE }\end{array}$ & $\begin{array}{l}\text { Alternative GWHS-3 } \\
\text { Pump \& Treat }\end{array}$ \\
\hline \multicolumn{4}{|c|}{ Overall Protectiveness } \\
\hline Human Health & $\begin{array}{l}\text { Not protective of groundwater } \\
\text { migration from source area toward } \\
\text { Pen Branch }\end{array}$ & Protective & Protective \\
\hline Environment & Not protective & Protective & Protective \\
\hline \multicolumn{4}{|c|}{ Effectiveness in Meeting Remedial Action Objectives } \\
\hline $\begin{array}{l}\text { Prevent migration in } \\
\text { groundwater }\end{array}$ & Not effective & $\begin{array}{l}\text { Moderately effective; contaminants in } \\
\text { groundwater hot spot removed }\end{array}$ & $\begin{array}{l}\text { Moderately effective; contaminated } \\
\text { groundwater hot spot would be removed } \\
\text { and hydraulically contained }\end{array}$ \\
\hline $\begin{array}{l}\text { Reduce toxicity, } \\
\text { mobility, or volume } \\
\text { of COCs through } \\
\text { treatment }\end{array}$ & Not effective & $\begin{array}{l}\text { Effective; } 99.5 \% \text { contaminants in } \\
\text { groundwater hot spot would be removed } \\
\text { - }\end{array}$ & $\begin{array}{l}\text { Effective; } 99.5 \% \text { contaminants in } \\
\text { groundwater hot spot would be removed } \\
\text { and treated }\end{array}$ \\
\hline $\begin{array}{l}\text { Effectiveness in } \\
\text { Meeting Remediation } \\
\text { Goals }\end{array}$ & Goals not met & Effective in reducing VOC concentration & $\begin{array}{l}\text { Effective in reducing VOC concentration } \\
\text { if formation permeabilities are relatively } \\
\text { high }\end{array}$ \\
\hline \multicolumn{4}{|c|}{ Compliance With ARARs } \\
\hline Chemical-specific & Would not meet MCLs & $\begin{array}{c}\text { Would not meet MCLs during Interim Action } \\
.\end{array}$ & $\begin{array}{l}\text { Would not meet MCLs during Interim } \\
\text { Action }\end{array}$ \\
\hline Location-specific & Not applicable & $\begin{array}{l}\text { Measures required to prevent impact to } \\
\text { neighboring wetlands (Pen Branch) }\end{array}$ & $\begin{array}{l}\text { Measures required to prevent impact to } \\
\text { neighboring wetlands (Pen Branch) }\end{array}$ \\
\hline Action-specific & No action-specific ARARs & $\begin{array}{l}\text { RCRA groundwater Protection Standards } \\
\text { regulations apply for remediation of } \\
\text { contaminated groundwater; SC Toxic Air } \\
\text { Pollutant regulations apply to air emissions; } \\
\text { SC Fugitive Particulate regulations apply to } \\
\text { dust emissions; SC Construction and } \\
\text { Operating permits apply to well construction; } \\
\text { LDRs for all PPE and treatment residues }\end{array}$ & $\begin{array}{l}\text { NPDES regulations apply to discharge of } \\
\text { effluent from the groundwater treatment } \\
\text { system; plus the same action-specific } \\
\text { ARARs as Alternative GWHS-2 apply }\end{array}$ \\
\hline \multicolumn{4}{|c|}{ Long-Term Effectiveness and Permanence } \\
\hline $\begin{array}{l}\text { Magnitude of residual } \\
\text { risks }\end{array}$ & $\begin{array}{l}\text { Groundwater plume would be a } \\
\text { continued source of contaminant } \\
\text { migration to Pen Branch; residual } \\
\text { risks to future resident as a result of } \\
\text { groundwater ingestion }\end{array}$ & $\begin{array}{l}\text { Residual risks reduced; groundwater } \\
\text { contamination reduced } 100 \text {-fold }\end{array}$ & $\begin{array}{l}\text { Residual risks reduced; groundwater } \\
\text { contamination reduced } 100 \text {-fold }\end{array}$ \\
\hline Adequacy of controls & $\begin{array}{l}\text { Not adequately protective of future } \\
\text { resident or environment }\end{array}$ & $\begin{array}{l}\text { Not adequately protective of future resident } \\
\text { or environment }\end{array}$ & $\begin{array}{l}\text { Not adequately protective of future } \\
\text { resident or environment }\end{array}$ \\
\hline Permanence & Not permanent & $\begin{array}{l}\text { Permanently removes contaminants in } \\
\text { groundwater }\end{array}$ & $\begin{array}{l}\text { Permanently removes contaminants in } \\
\text { groundwater }\end{array}$ \\
\hline \multicolumn{4}{|c|}{ Reduction of Toxicity, Mobility, or Volume } \\
\hline $\begin{array}{l}\text { Treatment process } \\
\text { used and materials } \\
\text { treated }\end{array}$ & No active treatment & $\begin{array}{l}\text { In situ AS of groundwater; no offgas } \\
\text { treatment required. }\end{array}$ & $\begin{array}{l}\text { Extraction of groundwater with air } \\
\text { stripping/carbon adsorption. }\end{array}$ \\
\hline $\begin{array}{l}\text { Degree of expected } \\
\text { reduction in toxicity, } \\
\text { mobility, or volume }\end{array}$ & None & $\begin{array}{l}\text { Air sparging would reduce volume (mass) of } \\
\text { contaminants in groundwater hot spot }\end{array}$ & $\begin{array}{l}\text { Pumping with treatment by air } \\
\text { stripping/carbon adsorption would reduce } \\
\text { volume (mass) of contaminants in } \\
\text { groundwater hot spot }\end{array}$ \\
\hline $\begin{array}{l}\text { Amount of hazardous } \\
\text { materials destroyed or } \\
\text { treated }\end{array}$ & None & $\begin{array}{l}\text { Would treat } 10 \text { million gal of groundwater } \\
\text { insitu and reduce volume (mass) by } 130 \mathrm{~kg}\end{array}$ & $\begin{array}{l}\text { Would treat } 18 \text { million gal of } \\
\text { groundwater per year, reduce volume } \\
\text { (mass) by } 130 \mathrm{~kg}\end{array}$ \\
\hline
\end{tabular}


Table 8 Summary of the Groundwater Hot Spot alternative screening (Continued)

\begin{tabular}{|c|c|c|c|}
\hline & \multicolumn{3}{|c|}{ Corrective Measure/Remedial Action Alternatives for the Pits Area Groundwater Hot Spot } \\
\hline Criterion & $\begin{array}{l}\text { Alternative GW-1 } \\
\text { No Action }\end{array}$ & $\begin{array}{l}\text { Alternative GWHS-2 } \\
\text { Air Sparging with SVE }\end{array}$ & $\begin{array}{c}\text { Alternative GWHS-3 } \\
\text { Pump \& Treat }\end{array}$ \\
\hline \multicolumn{4}{|c|}{ Reduction of Toxicity, Mobility, or Volume (continued) } \\
\hline $\begin{array}{l}\text { Degree to which } \\
\text { treatment is } \\
\text { irreversible }\end{array}$ & No treatment & $\begin{array}{l}\text { Contaminant removal and treatment are } \\
\text { irreversible }\end{array}$ & $\begin{array}{l}\text { Contaminant removal and treatment are } \\
\text { irreversible }\end{array}$ \\
\hline $\begin{array}{l}\text { Types and quantities } \\
\text { of residuals remaining } \\
\text { after treatment }\end{array}$ & None & $\begin{array}{l}\text { Air emissions ( } 450 \mathrm{scfm}) \text {; condensate } \\
(2.5 \mathrm{gpd}) ; \text { soil cuttings }\left(162 \mathrm{yd}^{3}\right) ; \text { purge water } \\
(1.000 \mathrm{gal})\end{array}$ & $\begin{array}{l}\text { Soil cuttings }\left(172 \mathrm{yd}^{3}\right) \text {; purge water } \\
(1,000 \mathrm{gal}) ; \text { treated effluent }(48,000 \mathrm{gpd}) \text {; } \\
\text { spent carbon }(52 \mathrm{lb} / \mathrm{yr})\end{array}$ \\
\hline \multicolumn{4}{|c|}{ Short-term effectiveness } \\
\hline Risks to workers & None & $\begin{array}{l}\text { Minimal; potential risk from installation of AS } \\
\text { and SVE points using direct push technology; } \\
\text { potential vapor inhalation during sparging } \\
\text { system operation; OSHA and applicable work } \\
\text { safety and health regulations will be followed }\end{array}$ & $\begin{array}{l}\text { Minimal; potential risk due to inhalation } \\
\text { or direct contact during well drilling; } \\
\text { potential vapor inhalation during air } \\
\text { stripping system operation; OSHA and } \\
\text { applicable work safety and health } \\
\text { regulations will be followed }\end{array}$ \\
\hline Risk to community & None & $\begin{array}{l}\text { Negligible; no public areas near unit; off-site } \\
\text { transport of spent carbon }\end{array}$ & $\begin{array}{l}\text { Negligible; no public areas near unit; off- } \\
\text { site transport of spent carbon }\end{array}$ \\
\hline Risk to environment & None & $\begin{array}{l}\text { Minimal; potential risk during } \\
\text { injection/extraction point installation; permitted } \\
\text { air emissions }\end{array}$ & $\begin{array}{l}\text { Moderate; potential risk during well } \\
\text { drilling; permitted air emissions on site } \\
\text { (sparging offgas and air stripping); } \\
\text { permitted effluent discharges to Pen } \\
\text { Branch }\end{array}$ \\
\hline $\begin{array}{l}\text { Time to achieve } \\
\text { remedial action } \\
\text { objectives }\end{array}$ & 0 months & 72 months & $\begin{array}{l}209 \text { months (based upon relatively high } \\
\text { formation permeabilities) }\end{array}$ \\
\hline \multicolumn{4}{|l|}{ Implementabilty } \\
\hline $\begin{array}{l}\text { Availability of } \\
\text { materials, equipment, } \\
\text { contractors }\end{array}$ & Not applicable & Readily available & Readily available \\
\hline $\begin{array}{l}\text { Ability to construct } \\
\text { and operate the } \\
\text { technology }\end{array}$ & Not applicable & Straightforward, commonly used technologies & $\begin{array}{l}\text { Well demonstrated and commonly used } \\
\text { technologies; pump testing needed for } \\
\text { groundwater extraction design }\end{array}$ \\
\hline $\begin{array}{l}\text { Ability to obtain } \\
\text { permits/approvals } \\
\text { from other agencies }\end{array}$ & $\begin{array}{l}\text { Readily implementable; } \\
\text { 5-year remedy reviews } \\
\text { required }\end{array}$ & $\begin{array}{l}\text { Implementable; air emissions permit required; } \\
\text { 5-year remedy reviews required }\end{array}$ & $\begin{array}{l}\text { Implementable; air emissions permit and } \\
\text { NPDES discharge permit required; 5-year } \\
\text { remedy reviews required }\end{array}$ \\
\hline $\begin{array}{l}\text { Ability to monitor } \\
\text { effectiveness of } \\
\text { remedy }\end{array}$ & Not applicable & $\begin{array}{l}\text { Readily implementable; groundwater } \\
\text { monitoring required; air quality monitoring of } \\
\text { sparging offgas emissions required }\end{array}$ & $\begin{array}{l}\text { Implementable; groundwater monitoring } \\
\text { required; water quality monitoring of air } \\
\text { stripping effluent }\end{array}$ \\
\hline $\begin{array}{l}\text { Ease of undertaking } \\
\text { additional actions (if } \\
\text { required) }\end{array}$ & Not incompatible & $\begin{array}{l}\text { Not incompatible; some AS wells would } \\
\text { penetrate existing cap }\end{array}$ & $\begin{array}{l}\text { Not incompatible; future groundwater } \\
\text { actions may require abandonment of } \\
\text { extraction/ treatment system; some wells } \\
\text { would penetrate existing cap }\end{array}$ \\
\hline Time to implement & 0 months & 12 months construct/est & 5 months construct \\
\hline \multicolumn{4}{|l|}{ Cost } \\
\hline $\begin{array}{l}\text { Present Worth Capital } \\
\text { Cost }\end{array}$ & $\$ 0$ & $\$ 2,432,000$ & $\$ 3,121,000$ \\
\hline $\begin{array}{l}\text { Present Worth O\&M } \\
\text { Cost }\end{array}$ & $\$ 50,000$ & $\$ 786,000$ & $\$ 1,190,000$ \\
\hline $\begin{array}{l}\text { Total Present Worth } \\
\text { Cost }\end{array}$ & $\$ 50,000$ & $\$ 3,218,000$ & $\$ 4,311,000$ \\
\hline
\end{tabular}


Commercial vendors are readily available for treatment and disposal. However, the effectiveness of this GWHS-3 is highly dependent upon the formation permeability. Formation permeability is thought to be relatively low and may cause GWHS-3 to be impracticable to implement.

Costs associated with Alternative GWHS-3 include labor and materials for the installation of groundwater extraction wells, pumps, and air stripping/carbon adsorption treatment system, and the operation and maintenance of those extraction and treatment systems for a period of 5 years. Costs associated with administrative controls (maintenance of existing CMP Pits access controls, sampling of all media, site maintenance activities, etc.) are included for a period of 5 years.

\section{Proposed Interim Action}

The evaluated alternatives and estimated present worth costs for the ballast area, vadose zone and groundwater hot spot are listed in Table 9. This IAPP recommends the following remedial actions:
Ballast Area - Alternative BA-3: Excavate the Ballast Area Soils, Dispose Off Site, and Backfill to Grade

SRS proposes to remove Aroclor-1248 and pesticide contaminated soils. Contaminated soil in the ballast area with concentrations greater than the RGs listed in Table 1 will be removed and disposed of in an approved facility. The soils are listed and are subject to RCRA Land Disposal Restrictions and will have to go to an RCRA Subtitle C facility and which mandates treatment prior to disposal. After the soil removal, the area will be sampled and samples analyzed for the COCs to confirm that the COC concentrations meet the RGs. After confirmation, the excavated area will be backfilled to grade. The removal of contaminated soils will ultimately represent a final remedial action for the ballast area soils. A Land Use Control Implementation Plan will be required to address residual contamination. Estimated present worth costs associated with Alternative BA-3 are $\$ 2,866,000$.

Table 9. Soil and Groundwater Interim Action Alternatives and Costs

\begin{tabular}{|c|c|c|}
\hline & ALTERNATIVES & COST* \\
\hline \multicolumn{3}{|c|}{ Ballast Area } \\
\hline BA-1 & No Action & $\$ 50,000$ \\
\hline BA-2 & Install RCRA Cap over the Ballast Area & $\$ 3,473,000$ \\
\hline BA-3 & Remove the Ballast Area Soils, Dispose Off Site, and Backfill to Grade ** & $\$ 2,866,000$ \\
\hline \multicolumn{3}{|c|}{ Vadose Zone } \\
\hline VZ-1 & No Action & $\$ 50,000$ \\
\hline VZ-2 & Conduct Soil Vapor Extraction and Install Asphalt Cover ${ }^{* *}$ & $\$ 1,143,000$ \\
\hline \multicolumn{3}{|c|}{ Groundwater Hot Spot } \\
\hline GWHS-1 & No Action & $\$ 50,000$ \\
\hline GWHS-2 & Conduct Air Sparging in Groundwater with Soil Vapor Extraction** & $\$ 3,218,000$ \\
\hline GWHS-3 & Remove Groundwater and Treat Using Air Stripping/Carbon Adsorption & $\$ 4,311,000$ \\
\hline
\end{tabular}

*Five year capital, operations and maintenance period

**Preferred alternative 
Vadose Zone - Alternative VZ-2: Conduct Soil Vapor Extraction in Subsurface Soils and Install Asphalt Cover to Provide Infiltration Control An early remedial action is warranted to eliminate the continued release of VOCs to the groundwater. Figure 9 illustrates the proposed interim remedial action for the vadose zone and groundwater hot spot. The vadose zone will be treated via nested soil vapor extraction (SVE) points in the contamination area within and adjacent to the original chemical pits 18.3G and 18.1G. Nests of extraction points will consist of three to four individual extraction points with overlapping 10 to 20 foot screen intervals. Screen intervals will be positioned in such a fashion as to concentrate in the areas of probable highest permeability (i.e. stratigraphic intervals consisting principally of sand). Vadose zone extraction points are expected to have an area of influence of over 50 feet in diameter. Therefore, coverage in the vicinity of the $18.3 \mathrm{G}$ and $18.1 \mathrm{G}$ pit boundaries is significant but provides a high degree of certainty that the extraction system will be efficient and effective.

An asphalt cover will be installed over the vegetative layer of the existing cap. The cover will provide infiltration control in the area of the vadose zone extraction system, considering that the existing cap will be penetrated by injection and extraction points. The installation of the asphalt cover is consistent with the interim remedial action objectives. Estimated present worth costs associated with Alternative VZ-2 are $\$ 1,143,000$.

Groundwater Hot Spot - Alternative GWHS-2: Conduct Air Sparging with Soil Vapor Extraction in Groundwater Hot Spot

The groundwater hot spot treatment consists of two AS areas in the water table (Fields $A$ and $B$ ), coupled with SVE in the vadose zone just above the water table. AS/SVE in the groundwater hot spot will volatilize the contaminants in the groundwater and remove them from the soil vapor phase. The air sparging within the water table aquifer reduces VOC concentrations by promoting the volatilization of the VOCs from the water. SVE is required to remove the vapors from the vadose zone prior to condensation of the vapors. AS in conjunction with SVE offers the following advantages:

- SVE increases the volatility of the VOCs in the vadose zone and ventilates the vadose zone to facilitate removal of volatilized VOCs.
The air sparging points are expected to have an effective radius of approximately 15 feet. The local spacing of air sparging points and SVE points on Figure 8 is consistent with the anticipated effective area. The overall arrangement of AS/SVE fields is consistent with the demonstrated migration paths of the hot spot VOCs from the source area to the distal portions of the groundwater plume, and the highest known concentrations of VOCs. The large number of injection and extraction points will have a rapid and significant impact on the concentrations of VOCs within the water table in the vicinity of the pits and downgradient. In addition, the number and position of the points is appropriate for an interim action, considering that some points may be determined not to be as effective as others, and additional points may be added as needed based upon system operating performance. Estimated present worth costs associated with Alternative GWHS-2 are $\$ 3,218,000$.

\section{Section V.C Conclusions}

\section{Ballast Area Removal}

Remediation of the ballast area is needed to facilitate installation of AS/SVE points. Removal of contaminated soil in the Ballast area will also eliminate the potential for introduction of contaminants to deeper soil depths due to installation of AS/SVE points and eliminate ecological hazards.

Ballast area soils above RGs will be sent to a Subtitle C facility for treatment and disposal. Decontamination fluids will be tested and if below health based levels, will be disposed of on-unit. Waste disposition will be documented in the PostConstruction Report or by correspondence to US EPA and SCDHEC. In addition, confirmatory sampling will be performed to demonstrate that the ballast area RAOs and RGs have been met. Results of the confirmatory sampling will be documented in the Post-Construction Report. After confirmation, the excavated area will be backfilled to grade. 


\section{AS/SVE Installation}

Figure 9 is a conceptual drawing of the overall AS/SVE system. An AS and SVE remedial cell will consist of SVE surrounded by a number of AS wells. The number of sparging and SVE points in a cell is dependent upon the stratigraphic homogeneity of the aquifer and the vadose zone, and the thickness of the aquifer. The number of sparging/extraction cells used in a remedial action is dependent upon the total area to be remediated.

Per US EPA guidance, on presumptive response strategies for groundwater (EPA 1996), groundwater response actions should be implemented in a phased approach with provisions for monitoring and evaluating performance. In accordance with the phased approach provisions, AS/SVE is proposed to allow the treatment system design to be evaluated and optimized. The goal of the AS/SVE system will be to treat the $1000 \mu \mathrm{g} / \mathrm{VOC}$ isoconcentration contour. To calibrate and evaluate the remedial action, groundwater VOC concentrations within and adjacent to the treatment zone, air sparging radius of influence, and SVE VOC air emissions rates will be monitored.

For this interim action, it is proposed that the AS/SVE system will operate for approximately five years with an annual Performance Evaluation. As part of the interim remedial action, it is anticipated that the AS/SVE system would continue to operate to further remediate the vadose zone and groundwater hot spot until the system has completed the remediation or reached the point of diminishing returns. The point of diminishing returns is the point at which the effectiveness of active remediation is equivalent to the effectiveness of passive remediation. Remediation effectiveness will be determined by evaluating the (1) soil gas concentration, (2) rate of mass removal, (3) system response following restart, and (4) cost of operation. An assessment of these combined criteria will be used to recommend ceasing operations. A monthly extraction load of $1 / 10^{\text {th }}$ of the initial startup monthly extraction load is considered an indication that the system is approaching the point of diminishing returns. System modifications would consist of active and passive enhancements to the interim action system such as:

- Number, location and configuration of the cells may be changed to improve the performance of the system
- Sparging and extraction intervals within the cell may be modified to improve performance

- Positive and negative air flow rates, temperatures and pressures may be modified to improve performance

- After higher concentration areas targeted by this interim action become remediated to concentrations amenable to bioremediation, nutrients may be added to the air sparging system to enhance biodegradation

Upon completion of the characterization to determine the extent of the plume, an appropriate final strategy for the vadose zone and groundwater hot spot will be developed and the final Record of Decision will be submitted for review and approval consistent with the enclosed schedule (Figure 10).The AS/SVE design will be documented and finalized with the approval of SCDHEC and US EPA via the Corrective Measures Implementation/ Remedial Design/ Remedial Design Report/ Remedial Action Work Plan.

\section{Performance Monitoring}

The vadose zone and groundwater hot spot remediation effectiveness will be based upon direct measurement of the groundwater and monitoring of multiple AS/SVE parameters. The vadose zone SVE will be monitored for flow rates at extraction points and concentration of VOCs on the positive side of the SVE blowers. The rate of extraction and the VOC concentration will be used to calculate the quantity of VOCs removed from the vadose zone. The same technique will be used to monitor the quantity of VOCs removed from the groundwater. In addition, flow rates for air sparging points will be measured to determine injection performance. Inlet/outlet load testing will be performed per Air Quality Control permit requirements with response testing performed semi-annually during normal operations. All other performance monitoring will be completed quarterly during start-up and semiannually during normal operations.

Four water table wells within the hot spot and five water table wells downgradient of the hot spot will be monitored to review the performance of the treatment system (see Figure 8). Monitoring wells that are located within the treatment area will provide a direct measurement of air sparging effects on VOC concentration in the water table. 
Downgradient performance monitoring wells will measure the probable effect of the treatment system on the distal plume. Downgradient locations are positioned close enough to the treatment area to indicate the effect of air sparging, but not too close to measure short term system perturbations.

SRS assumes that contamination released in the vadose zone in 1971 reached the groundwater in 1979 and entered Pen Branch in 1997. Based on this, it has taken 19 years for the contamination to travel 1800 feet in the groundwater. Therefore, the contamination is travelling at 94.7 feet/year. The distance from the $1000 \mathrm{ppb}$ contour to the closest wells (CMP-38D and CMP-39D) is 66 feet. Therefore, it will take 0.7 years $(66 / 94.7)$ or 8 months for the groundwater to travel from the 1000 ppb contour to the downgradient monitoring well. In addition, the downgradient performance monitoring wells will provide additional information on the VOC concentrations to the north and in the area adjacent to the treatment area (area of lower permeability).

\section{SECTION VI INTEGRATED INTERIM AND FINAL ACTION IMPLEMENTATION SCHEDULE}

An integrated interim and final action implementation schedule is shown in Figure 10. A signed IROD is scheduled for $8 / 16 / 99$. The approval of the interim CMI/RD/RDR/RA WP is scheduled for 11/9/99. Construction start of the interim action would then begin by $12 / 10 / 99$.

Concurrent with the above interim action, a final action is scheduled. A detailed alternative screening process will be conducted for the final action in the CMS/FS. The CMS/FS will be scoped after the extent of the distal portion of the plume is known. A Statement of Basis/Proposed Plan will be submitted at the same time as the CMS/FS on 3/31/00. Upon approval of the SB/PP, the public comment period will commence and the final ROD will be submitted within fourteen days after the completion of the public comment period.

This schedule is consistent with the approved operable unit strategy and approved extension request for the CMP Pits. It provides the shortest path forward to a final ROD for this unit as agreed to by the three parties. The major outstanding question relative to this unit is the extent of the distal plume. The extent of the distal plume is currently being characterized as indicated in the schedule. A decision document will be developed based on the characterization results and a decision meeting between the three parties will be held September 1, 1999. At this time, it will be determined if a final action can be determined for the distal plume or whether or not additional information is needed such as the effectiveness of source control at the unit. If necessary, the operable unit strategy would be revised as a result of this decision meeting. 


\section{REFERENCES}

DOE, 1994. Public Involvement, A Plan for Savannah River Site, Savannah River Operations Office, Aiken, South Carolina, 1994.

DOE, 1996. Savannah River Site Future Use Project Report Stakeholder Recommendations for SRS Land and Facilities $(U)$, Savannah River Operations Office, Aiken, South Carolina, January 1996.

EPA (U.S. Environmental Protection Agency), 1989. Guidance on Preparing Superfund Decision Documents: The Proposed Plan. The Record of Decision. Explanation of Significant Differences, The Record of Decision Amendment. EPA/540/G$89 / 007$, Office of Emergency and Remedial Response, Washington, DC (July).

EPA (U.S. Environmental Protection Agency), 1996. Final Guidance: Presumptive Response Strategy and Ex-Situ Treatment Technologies for Contaminated Ground Water at CERCLA Sites. Directive 9283.112, EPA 540/R-96/023, PB96-963508, Office of Solid Waste and Emergency Response, Washington, DC (October).

FFA, 1993. Federal Facility Agreement for the Savannah River Site, Administrative Docket No. 8905-FF, Effective Date: August 16, 1993, WSRC-OS94-42.

OSWER 9234.2-01/FS-A, ARARs $Q$ 's \& A's: General Policy, RCRA, CWA, SDWA, Post-ROD Information, and Contingent Waivers.

OSWER 9347.3-09FS, A Guide to Delisting of RCRA Wastes for Superfund Remedial Responses.

Woodward-Clyde, 1985. Second Draft Preliminary Site Closure Plan CMP Pits, Savannah River Plant, Aiken, South Carolina.

WSRC, $1997 . \quad$ RCRA Facility Investigation/Remedial Investigation Report with Baseline Risk Assessment for the Chemicals, Metals and Pesticides (CMP) Pits (080-17G, 080-17.1G, 080-18.1G, 080-18.2G, 080-18.3G, \& 080-19G) (U), Volumes I and II, WRSC-RP-96-00112, Revision 1.2, Westinghouse Savannah River Company, Savannah River Site, Aiken, South Carolina, (August).
WSRC, 1998. Corrective Measures Study/Feasibility Study for the Chemicals, Metals and Pesticides (CMP) Pits (080-17G, 080-17.1G, 080-18.1G, 080$18.2 G, 080-18.3 G, \& 080-19 G)(U)$, WRSC-RP-96124, Revision 1.2, Westinghouse Savannah River Company, Savannah River Site, Aiken, South Carolina, (January). 
ACTIVITY
Description

CHARACTERTZATION

DISTAL PLUME CHAR SUPPORTING REV 1.3 CMS/FS

SRS DEVELOP DECISION DOCUMENT

EPA/SCDHEC REVIEW DECISION DOCUMENT

DECISION MEETINC

RFI/RI/BRA REPORT

SRS SUBMITTAL OF REV. 1.2 RFI/RI/BRA REPORT

EPA/SCDHEC FINAL REVIEW \& APPROVAL

RECEIPT OF EPA/SCDHEC APPROVAL

CMS/FS/PP \& DRAFT ROD

DEVEL REV 1.3 CMS/FS \& SB/PP REV O \& DRAFT ROD

SRS SUB OF REV. 1.3 CMS/FS \& SB/PP REV 0 \&D ROD EPA/SCDHEC REVIEW \& COMMENT

SRS INCORPORATE COMMENTS

EPA/SCDHEC APPROVAL OF CMS/FS \& SB/PP

NOTIFICATION OF PUBLIC COMMENT PERIOD

PUBLIC COMMENT PERIOD RECORD OF DECISION

DEVELOP ROD

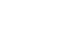

\section{RESPONSTVENESS SUMMARY \& APPROVALS}

SRS SUBMITTAL OF REV. O ROD

EPA/SCDHEC REVIEW

SRS IMCORPORATE EPA/SCDHEC COMMENTS

EARLY EARLY

ORIG

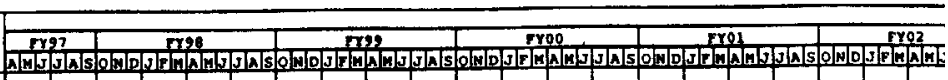

SRS SUBMITTAL OF REV. 1 ROD

EPA/SCDHEC FINAL REVIEW \& APPROVAL

SUBMIT SIGNED ROD TO EPA/SCDHEC

CORRECTIVE MEASURE/REMEDIAL DESIGN WORKPLAN

\section{DEVELOP CMI/RD/RDR/RA WP}

SRS SUBMITTAL OF REV.O CMI/RD/RDR/RA WP

EPA/SCDHEC REVIEW

SRS INCORPORATE EPA/SCHDEC COMMENTS

SRS SUBMITTAL OF REV.1 CMT/RD/RDR/RA WP

\begin{tabular}{|c|c|c|}
\hline 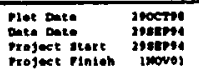 & orp & $\left.\right|^{\infty+\infty}$ \\
\hline
\end{tabular}

240 CT00

1 JUL99 30JUL99

187

-

$-1$

1 SEP99

$+$.

2.

28AUG97

$10 \mathrm{CT} 97$ 0

\begin{tabular}{ll}
$10 C T 97$ & 0 \\
\hline
\end{tabular}

2SEP99

31MAROO $\quad 145$

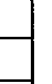

5 APROO 3JULOO

\begin{tabular}{lll} 
5JULOO & 2SULOO & 90 \\
\hline
\end{tabular}

\begin{tabular}{|ccc|}
\hline 3SEPOO & 20 CT00 & 30 \\
\hline 30 CTOO & 160 CT00 & 14 \\
\hline 170 CTOO & 30 NOVOO & 45 \\
\hline
\end{tabular}

28JuL00 29Nov00 86 


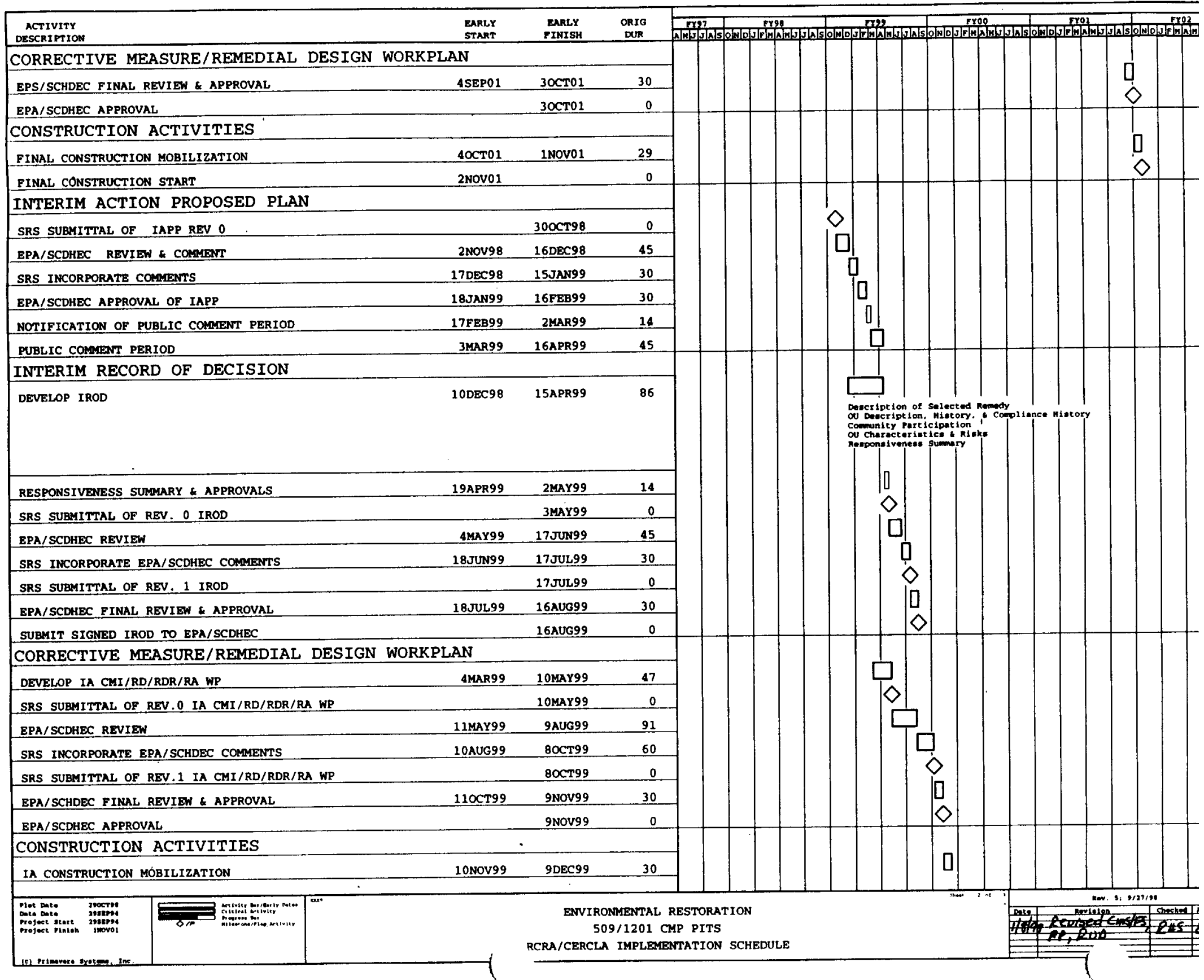




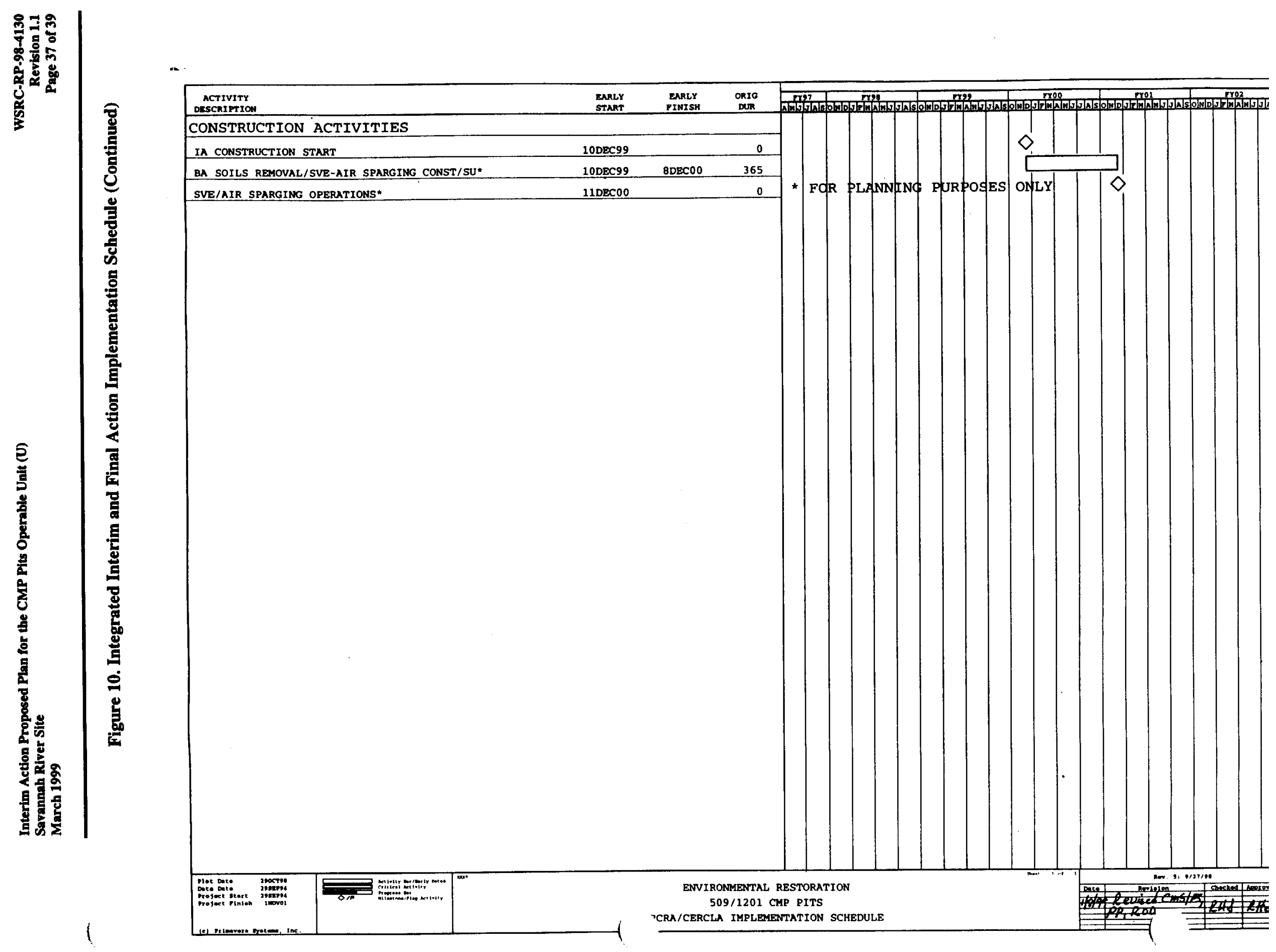




\section{GLOSSARY}

Administrative Record File: A file that is maintained and contains all information used to make a decision on the selection of a response action under the Comprehensive Environmental Response, Compensation and Liability Act or a corrective action under RCRA. This file is to be available for public review, and a copy is to be established at or near the SRS, usually at one of the information repositories. Also a duplicate file is held in a central location, such as a regional or state office.

ARARs: Applicable, or Relevant and Appropriate Requirements. Refers to the federal and state requirements that a selected remedy will attain. These requirements may vary from site to site.

Baseline Risk Assessment: Analysis of the potential adverse health and ecological effects (current or future) caused by hazardous substance release from a site in the absence of any actions to control or mitigate these releases.

Characterization: The compilation of all available data about the waste units to determine the rate and extent of contaminant migration resulting from the waste site, and the concentration of any contaminants that may be present.

\section{Comprehensive Environmental Response,} Compensation and Liability Act (CERCLA), 1980: A Federal law passed in 1980 and modified in 1986 by the Superfund Amendments and Reauthorization Act. The Acts created a special tax that goes into a Trust Fund, commonly known as Superfund, to investigate and clean up abandoned or uncontrolled hazardous waste sites.

Corrective Action: A US EPA requirement to conduct remedial procedures under RCRA 3998(h) at a facility when there has been a release of hazardous waste or constituents into the environment. Corrective action may be required beyond the facility boundary and can be required regardless of when the waste was placed at the facility.

Distal Plume: The portion of the groundwater contamination located away from the source or origin. The CMP Pits distal plume is defined as the portion of the groundwater contamination where the total VOC concentration is less than $1000 \mu \mathrm{g} /$.
Exposure: Contact of an organism with a chemical or physical agent. Exposure is quantified as the amount of the agent available at the exchange boundaries of the organism (e.g., skin, lungs, digestive tract, etc.) and available for absorption.

Federal Facility Agreement (FFA) (FFA 1993): The legally binding agreement between regulatory agencies (US EPA and SCDHEC) and regulated entities (US DOE) that sets the standards and schedules for the comprehensive remediation of the SRS.

Human Health Primary COC: Chemical or radionuclide in a medium with a cumulative noncancer hazard index (HI) greater than 3 or a cumulative excess lifetime cancer risk (ELCR) greater than $1 \times 10^{-4}$. Primary $\mathrm{COC}$ has a constituent-specific noncancer hazard quotient greater than or equal to 0.1 or a cancer risk greater than or equal to $1 \times 10^{-6}$. Chemical that exceeds an applicable or relevant and appropriate requirement (ARAR) (e.g., MCLs), but does not exceed an ELCR of $1 \times 10^{-4}$ or an $\mathrm{HI}$ of 3 is also retained as primary COC.

Human Health Secondary COC: Chemical or radionuclide in a medium with a cumulative noncancer $\mathrm{HI}$ between 1 and 3 or a cumulative ELCR between $1 \times 10^{-6}$ and $1 \times 10^{-4}$. Secondary $\mathrm{COC}$ has a constituent-specific noncancer hazard quotient greater than or equal to 0.1 or a cancer risk greater than or equal to $1 \times 10^{-6}$.

Media: A pathway through which contaminants are transferred. Media by which contaminants may be transferred are groundwater, soil, surface water, sediments, air, and biota.

National Priorities List (NPL): US EPA's formal list of the nation's most serious uncontrolled or abandoned waste sites, identified for possible long term remedial response, as established by CERCLA.

Operable Unit (OU): A discrete action taken as one part of an overall site cleanup. The term is also used in US EPA guidance documents to refer to distinct geographic areas or media-specific units within a site. A number of operable units can be used in the course of a cleanup. 
Operation and Maintenance: Activities conducted at a site after response action occurs to ensure that the cleanup and/or systems are functioning properly.

Overall Protection of Human Health and the Environment: The assessment against this criterion describes how the alternative, as a whole, achieves and maintains protection of human health and the environment.

Proposed Plan: A legal document that provides a brief analysis of remedial alternatives under consideration for the site/operable unit and proposes the preferred alternative. It actively solicits public review and comment on all alternatives under consideration.

Resource Conservation and Recovery Act (RCRA), 1976: A Federal law that established a regulatory system to track hazardous substances from their generation to disposal. The law requires safe and secure procedures to be used in treating, transporting, storing, and disposing of hazardous substances. RCRA is designed to prevent the creation of new, uncontrolled hazardous waste sites.

Record of Decision (ROD): A legal document that explains to the public which alternative will be used at a site/operable unit. The record of decision is based on information and technical analysis generated during the remedial investigation/feasibility study and consideration of public comments and community concerns.

Responsiveness Summary: A summary of oral and/or written comments received during the proposed plan comment period that includes responses to those comments. The responsiveness summary is a key part of the ROD, highlighting community concerns.

Statement of Basis: A report describing the corrective measures/remedial actions being conducted pursuant to South Carolina Hazardous Waste Management Regulations, as amended.

Superfund: The common name used for CERCLA; also referred to as the Trust Fund. The Superfund program was established to help fund cleanup of hazardous waste sites. It also allows for legal action to force those responsible for the sites to clean them up. 